\title{
Natural sea-salt emissions moderate the climate forcing of anthropogenic nitrate
}

\author{
Ying Chen ${ }^{1,2,3,9}$, Yafang Cheng ${ }^{2}$, Nan $\mathbf{M a}^{4,2,3,1}$, Chao Wei ${ }^{3}$, Liang $\operatorname{Ran}^{5}$, Ralf Wolke ${ }^{6}$, Johannes Größ ${ }^{1}$, \\ Qiaoqiao Wang ${ }^{4}$, Andrea Pozzer ${ }^{7}$, Hugo A. C. Denier van der Gon ${ }^{8}$, Gerald Spindler ${ }^{10}$, Jos Lelieveld ${ }^{7,11}$, Ina Tegen ${ }^{6}$, \\ Hang $\mathrm{Su}^{3}$, and Alfred Wiedensohler ${ }^{1}$ \\ ${ }^{1}$ Department Experimental Aerosol and Cloud Microphysics, Leibniz Institute for Tropospheric Research, \\ Leipzig, Germany \\ ${ }^{2}$ Minerva Research Group, Max Planck Institute for Chemistry, Mainz, Germany \\ ${ }^{3}$ Multiphase Chemistry Department, Max Planck Institute for Chemistry, Mainz, Germany \\ ${ }^{4}$ Center for Pollution and Climate Change Research (APCC), Institute for Environmental and Climate Research, \\ Jinan University, Guangzhou, China \\ ${ }^{5}$ Key Laboratory of Middle Atmosphere and Global Environment Observation, Institute of Atmospheric Physics, \\ Chinese Academy of Sciences, Beijing, China \\ ${ }^{6}$ Modelling of Atmospheric Processes, Leibniz Institute for Tropospheric Research, Leipzig, Germany \\ ${ }^{7}$ Atmospheric Chemistry Department, Max Planck Institute for Chemistry, Mainz, Germany \\ ${ }^{8}$ TNO, Department of Climate, Air and Sustainability, Princetonlaan 6, Utrecht, the Netherlands \\ ${ }^{9}$ Lancaster Environment Centre, Lancaster University, Lancaster, UK \\ ${ }^{10}$ Atmospheric Chemistry Department, Leibniz Institute for Tropospheric Research, Leipzig, Germany \\ ${ }^{11}$ The Cyprus Institute, Nicosia, Cyprus
}

Correspondence: Yafang Cheng (yafang.cheng@mpic.de) and Ying Chen (chen@tropos.de)

Received: 10 June 2019 - Discussion started: 12 August 2019

Revised: 16 November 2019 - Accepted: 19 December 2019 - Published: 22 January 2020

\begin{abstract}
Natural sea-salt aerosols, when interacting with anthropogenic emissions, can enhance the formation of particulate nitrate. This enhancement has been suggested to increase the direct radiative forcing of nitrate, called the "massenhancement effect". Through a size-resolved dynamic mass transfer modeling approach, we show that interactions with sea salt shift the nitrate from sub- to super-micron-sized particles ("redistribution effect"), and hence this lowers its efficiency for light extinction and reduces its lifetime. The redistribution effect overwhelms the mass-enhancement effect and significantly moderates nitrate cooling; e.g., the nitrateassociated aerosol optical depth can be reduced by $10 \%-$ $20 \%$ over European polluted regions during a typical seasalt event, in contrast to an increase by $\sim 10 \%$ when only accounting for the mass-enhancement effect. Global model simulations indicate significant redistribution over coastal and offshore regions worldwide. Our study suggests a strong buffering by natural sea-salt aerosols that reduces the climate
\end{abstract}

forcing of anthropogenic nitrate, which had been expected to dominate the aerosol cooling by the end of the century. Comprehensive considerations of this redistribution effect foster better understandings of climate change and nitrogen deposition.

\section{Introduction}

Particulate nitrate $\left(\mathrm{NO}_{3}^{-}\right)$is one of the most important anthropogenic aerosol components that exerts a climate cooling effect (IPCC, 2013; Haywood and Schulz, 2007). On a global scale, its average direct radiative forcing (DRF) has been estimated to span over a relatively wide range from -0.08 to $-0.19 \mathrm{~W} \mathrm{~m}^{-2}$ (Liao et al., 2004; Liao and Seinfeld, 2005; IPCC, 2013; Xu and Penner, 2012; Haywood and Schulz, 2007; Myhre et al., 2013; Forster et al., 2007; Adams et al., 2001; Bauer et al., 2007; Jacobson, 2001; Streets et al., 
2013; van Dorland et al., 1997). It is projected to reach up to about -0.4 to $-1.3 \mathrm{~W} \mathrm{~m}^{-2}$ and dominate the aerosol cooling by the end of the century (Adams et al., 2001; Bellouin et al., 2011; Hauglustaine et al., 2014). Although the gaseous precursors of nitrate, e.g., $\mathrm{NO}_{x}\left(\mathrm{NO}+\mathrm{NO}_{2}\right)$ and $\mathrm{HNO}_{3}$, are mainly of anthropogenic origin, globally about $35 \%-50 \%$ of the nitrate mass is associated with natural sea-salt aerosol (Xu and Penner, 2012; Myhre et al., 2006). This is because sea-salt aerosol can be transported over industrialized regions, interacts with anthropogenic precursors of nitrate and enhances the total nitrate column loading in the atmosphere through heterogeneous uptake of $\mathrm{HNO}_{3}$ and its precursors (Liao et al., 2004; Liao and Seinfeld, 2005; Seinfeld and Pandis, 2006; Xu and Penner, 2012; Ravishankara, 1997; Lowe et al., 2015). Such sea-salt-induced nitrate mass increase is believed to strengthen the DRF and climate cooling of nitrate (Liao and Seinfeld, 2005), called the "mass-enhancement effect".

However, not only the mass concentration but also the particle mass size distribution (PMSD) is essential for evaluating the direct radiative forcing of nitrate $\left(\mathrm{DRF}_{\text {nitrate }}\right)$ (IPCC, 2013; Murphy et al., 1998; Kok et al., 2017). Besides leading to the increase of total nitrate mass, interactions with sea-salt aerosol also have a "redistribution effect" on nitrate PMSD, which shifts nitrate from sub- to super-micron sizes (e.g., Chen et al., 2016a; see also Fig. 1). Because sea-salt aerosol is mainly present as super-micron (coarse) particles (Murphy et al., 1998; O'Dowd et al., 1997; Ravishankara, 1997), chemical equilibrium favors the formation of thermodynamically stable sodium nitrate in the coarse mode, which inhibits the formation of semivolatile ammonium nitrate in the submicron size (fine mode) through competitive consumption of gaseous precursors and change in the gasparticle equilibrium (Chen et al., 2016a; Zaveri et al., 2008; Myhre et al., 2006). Compared to the fine particles, coarse particles have a significantly lower extinction efficiency in the visible part of the spectrum (IPCC, 2013; Murphy et al., 1998); the sea-salt-induced redistribution effect thus tends to weaken $D_{R F}$ nitrate, which counteracts the mass-enhancement effect. The competition between these two effects will ultimately determine the net impact of sea-salt aerosol on an-

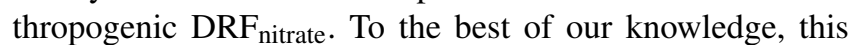
sea-salt-induced redistribution effect is neglected in most global models, due to the computationally expensive calculations of fully dynamic mass transfer between size-resolved particulate nitrate (Adams et al., 2001; Myhre et al., 2006); for more details, see the Supplement Sect. S1.

To explore the competition between the sea-salt-induced mass-enhancement effect and redistribution effect and the impact of the redistribution process on the nitrate cooling of climate, we conducted a series of sensitivity studies with and without sea-salt aerosol emission for a typical sea-salt event over Europe and North America, using a regional atmospheric chemistry model (WRF-Chem) with a fully dynamic mass transfer approach (Zaveri et al., 2008); see "Data and

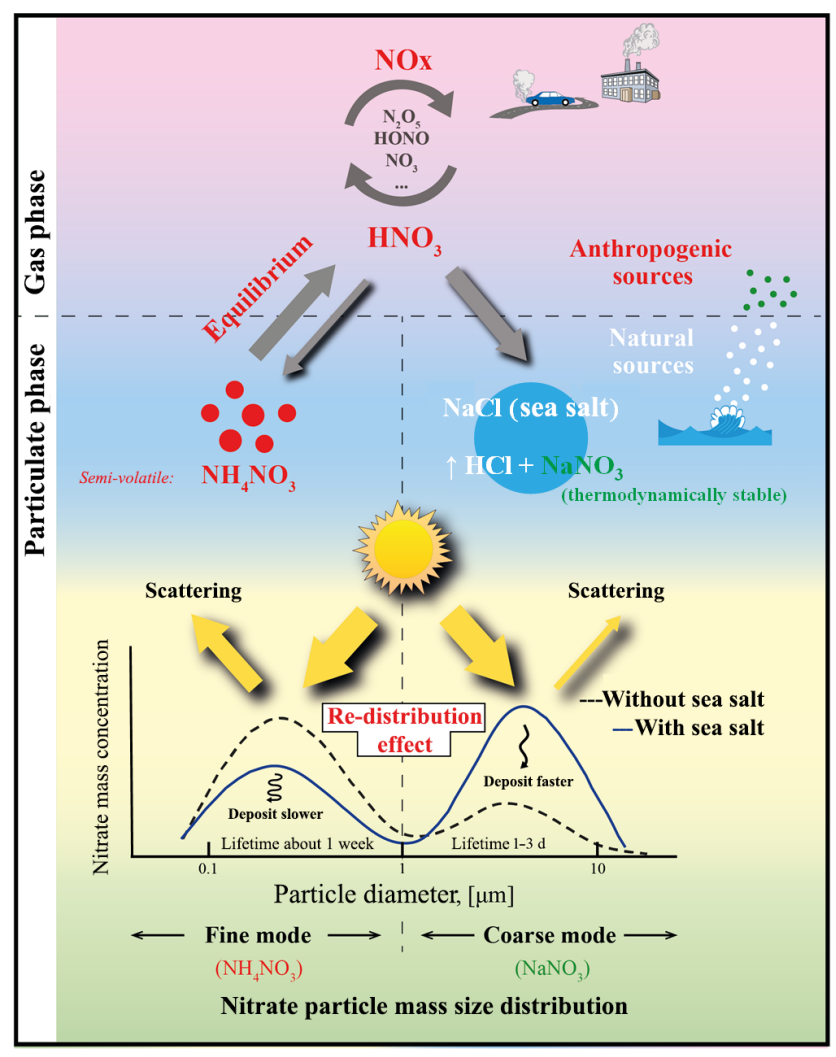

Figure 1. Concept of the redistribution effect induced by sea-salt aerosol.

methods" for details. A 1-year simulation with the EMAC (ECHAM5/MESSy Atmospheric Chemistry) model is used to demonstrate the importance of the redistribution effect on a global scale (Jöckel et al., 2010).

\section{Data and methods}

\subsection{Observations}

The HOPE campaign $\left(\mathrm{HD}(\mathrm{CP})^{2}\right.$ Observational Prototype Experiment, Macke et al., 2017) was carried out during 10-20 September 2013 at Melpitz, Germany $\left(51.53^{\circ} \mathrm{N}\right.$, $12.93^{\circ} \mathrm{E} ; 86 \mathrm{~m}$ a.s.1.). Melpitz represents the regional background of central Europe (Spindler et al., 2012), with flat surrounding topography over an area of hundreds of square kilometers, ranging 100-250 $\mathrm{m}$ a.s.l.

Size-segregated measurements of particle composition were carried out on 13 and 18 September, which represent the continental period and marine period, respectively (see back-trajectories in Fig. S1 in the Supplement). A fivestage Berner impactor (Hauke, Austria, 0.05-0.14, 0.14$0.42,0.42-1.2,1.2-3.5$ and 3.5-10 $\mu \mathrm{m}$; Berner and Luerzer, 1980) was operated to segregate particles onto ring-like prebaked $\left(350^{\circ} \mathrm{C}\right)$ aluminum foils with a sampling period of $24 \mathrm{~h}$ (00:00-24:00, local time) for detailed chemical analy- 
ses (Spindler et al., 2012). The isokinetic inlet for particles with an aerosol dynamic diameter smaller than $10 \mu \mathrm{m}$ was installed $6 \mathrm{~m}$ above the ground. To compare with modeling results, we use the sum of the particle mass at stage $1-3\left(\mathrm{PM}_{1.2}\right.$, aerosol dynamic diameter smaller than $1.2 \mu \mathrm{m})$ to represent fine-mode particles and the sum of the mass at stages 4-5 $\left(\mathrm{PM}_{1.2-10}\right.$, aerosol dynamic diameter smaller between 1.2 and $10 \mu \mathrm{m})$ to represent coarse-mode particles. The gravimetric mass of the preheated aluminum foils was weighted before and after the sampling process, by a microbalance (UMT-2, Mettler-Toledo, Switzerland). Before each weighting, the aluminum foils were equilibrated for at least $72 \mathrm{~h}$ in a strictly controlled environment with a temperature of $20 \pm 1^{\circ} \mathrm{C}$ and a relative humidity of $50 \pm 5 \%$. After an aqueous extraction of foil aliquots, the main water-soluble cations $\left(\mathrm{Na}^{+}, \mathrm{NH}_{4}^{+}, \mathrm{K}^{+}, \mathrm{Mg}^{2+}\right.$ and $\left.\mathrm{Ca}^{2+}\right)$ were quantified by standard ion chromatography (Neusüß et al., 2000). Likewise, capillary electrophoresis (Neusüß et al., 2000) was carried out to quantify the anions $\left(\mathrm{NO}_{3}^{-}, \mathrm{SO}_{4}^{2-}\right.$ and $\left.\mathrm{Cl}^{-}\right)$. A carbon analyzer (Behr Labor-Technik, Germany) was used to separate and measure the sampled organic and elemental carbon with a two-step thermographic method (modified VDI method 2465 part-2; Spindler et al., 2012). Organic carbon was vaporized at $650^{\circ} \mathrm{C}$ for $8 \mathrm{~min}$ under $\mathrm{N}_{2}$ and catalytically converted to $\mathrm{CO}_{2}$; the remaining elemental carbon was combusted for another $8 \mathrm{~min}$ with $\mathrm{O}_{2}$ at $650^{\circ} \mathrm{C}$. Generated $\mathrm{CO}_{2}$ was then quantitatively determined using a nondispersive infrared detector.

\subsection{Model description}

We performed regional model simulations with the "online coupled" air quality model Weather Research and Forecasting with Chemistry model (WRF-Chem V3.5.1; Grell et al., 2005). WRF-Chem enables more detailed investigation of aerosol-radiation interaction over specific regions at higher horizontal resolution compared with global models, and it has been broadly used for investigating aerosol radiative forcing in previous studies (e.g., Archer-Nicholls et al., 2019; Fast et al., 2006; Saide et al., 2012; Gao et al., 2018; Yao et al., 2017; Huang et al., 2015). To investigate the impact of redistribution effect on PMSD and climate effect of nitrate, the fully dynamic aerosol module MOSAIC (Zaveri et al., 2008) was utilized with eight discrete size bins (39-78, 78-156, 156-312, 312-625, 625-1250 nm, 1.25-2.5, 2.5-5, 5-10 $\mu \mathrm{m}$; see also Fig. 2), with the online coupled CBMZ (CarbonBond Mechanism version Z) gas chemistry scheme (Zaveri and Peters, 1999). In MOSAIC, $\mathrm{NaCl}$ reacts irreversibly with nitric acid with its equilibrium surface vapor pressure of zero; a gas-particle partitioning approach ASTEM (Adaptive Step Time-Split Euler Method) is coupled with a thermodynamic module (MESA-MTEM, Multicomponent Equilibrium Solver for Aerosols - Multicomponent Taylor Expansion Method) to dynamically calculate the equilibrium vapor pressure and condensation rate of semivolatile ammo- nium nitrate; details are given in the Sect. 4 of Zaveri et al. (2008). We note that heterogeneous hydrolysis of $\mathrm{N}_{2} \mathrm{O}_{5}$ with $\mathrm{NaCl}$ is an important chemical pathway of particulate nitrate in coarse mode during nighttime (Bertram and Thornton, 2009; Archer-Nicholls et al., 2014). This process may enhance the redistribution effect; however, it is not considered in this study. The sea-salt emissions computed with the modified Gong scheme (Gong, 2003) were reduced to $10 \%$ in the "Case_SeasaltOn" simulation, because a previous study (Chen et al., 2016a) has shown that the original Gong scheme overestimates the sea-salt mass concentrations by a factor of $\sim 10$ over the coastal regions of Europe using the WRF-Chem model. We note that although the mass of coarse sea-salt particles is certainly overestimated, it might not necessarily indicate overestimation in fine sea-salt particles related to their minor contribution to the total mass. The sea-salt emission was turned off in the "Case_SeasaltOff" simulation. We calculate the DRF and aerosol optical depth of anthropogenic nitrate at the top of the atmosphere for both sea-salt emission cases, based on the difference in the net incoming radiative flux with and without the anthropogenically emitted gas-phase precursor $\mathrm{NO}_{x}$ (IPCC, 2013; Xu and Penner, 2012). Only the model results during daytime (07:00 16:00, local time) and under clear-sky condition (cloud optical depth equals to zero) were used for the analyses of DRF in this study.

WRF-Chem calculated aerosol optical depth (AOD) and direct radiative effect of total aerosols based on the internal mixture assumption and taking the hygroscopicity into account. In order to calculate the light extinction coefficient and optical depth for individual aerosol species, we performed the following off-line calculation. The AOD of each species is calculated by integrating light extinction coefficient $\left(\sigma_{\mathrm{ex}}\right)$ over all vertical layers. The $\sigma_{\mathrm{ex}}$ of sea salt $(\mathrm{NaCl})$ and particulate nitrate were calculated with Mie theory, based on their PMSD. Different from the WRF-Chem calculation of total aerosol AOD, an external mixture was assumed for nitrate and sea-salt particles when calculating their respective contributions on $\sigma_{\mathrm{ex}}$ or AOD. Hygroscopic growth was also considered, following the $\kappa$-Köhler theory (Köhler, 1936; Petters and Kreidenweis, 2007).

\subsection{European simulation}

The European simulations focus on the HOPE-Melpitz campaign period of 10-20 September 2013, during which a seasalt event that influenced most of Europe was captured. The simulations are defined by two nested domains with horizontal resolutions of 54 and $18 \mathrm{~km}$ and 39 vertical layers with model top at $50 \mathrm{hPa}$. The coarse domain (D01) covers the North Sea, the European continent and the northern part of Africa; the inner domain (D02) covers most of the North Sea and the European continent (Fig. S2). The European anthropogenic emission inventories are provided by TNO (https://www.tno.nl, last access: 17 January 2020), 
(a)

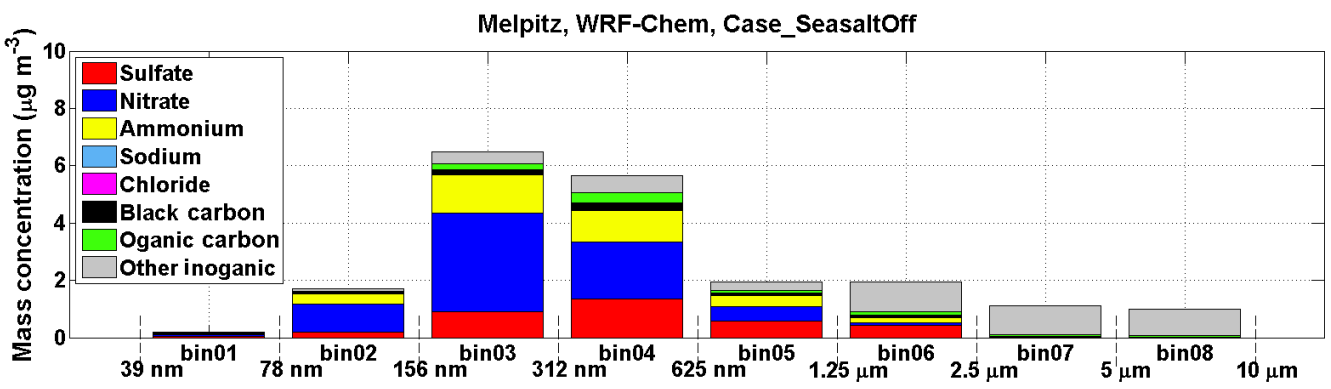

(b)

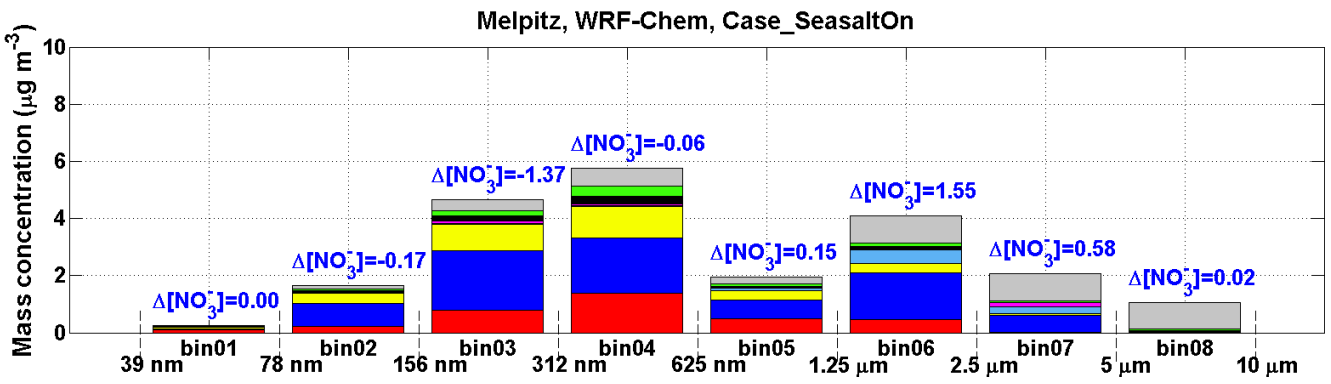

Figure 2. Model results of mass concentration of each chemical compound in eight size bins at Melpitz. The results shown here are averaged during 17 September 2013 when marine air masses started approaching Melpitz. Sodium is used as an indicator of sea-salt aerosol. (a) Result of the "Case_SeasaltOff" simulation (without sea-salt emission). (b) Result of the "Case_SeasaltOn" simulation (with sea-salt emission). The differences between particulate nitrate mass concentration $\left(\Delta\left[\mathrm{NO}_{3}^{-}\right]\right)$in each size bin are marked.

from the AQMEII project (Air Quality Model Evaluation International Initiative) for $\mathrm{PM}_{2.5}, \mathrm{PM}_{2.5-10}, \mathrm{NO}_{x}, \mathrm{SO}_{2}, \mathrm{CO}$, $\mathrm{NH}_{3}$ and nonmethane volatile organic compounds (Pouliot et al., 2012; Chen et al., 2018b), and from the EUCAARI project (European Integrated project on Aerosol, Cloud, Climate, and Air Quality Interactions) for particulate organic carbon and elemental carbon (Kulmala et al., 2011). The inventories are with a spatial resolution of $1 / 8^{\circ} \times 1 / 16^{\circ}$ longitude-latitude. We excluded the point source emissions of elemental carbon in the EUCAARI inventory over Germany since a previous study (Chen et al., 2016b) reported large uncertainty for them. More details about emissions and meteorological and chemical initial and boundary conditions can be found in Sect. S2. Detailed information about the model configuration is given in Table 1 .

In the European Case_SeasaltOn simulation (with seasalt emission), modeled $\left[\mathrm{Na}^{+}\right]$showed good agreement with measurements over coastal regions from the European Monitoring and Evaluation Programme (EMEP, https: //www.emep.int, last access: 17 January 2020), with a factor (and correlation coefficient) of 0.85 (0.67), $1.16(0.80)$ and 0.83 (0.87) for Bilthoven, Kollumerwaard and Vredepeel (Fig. S3), respectively. Compared with ground-based measurements at Melpitz and radio-sounding measurements across Europe, the meteorological conditions were well captured by the model (Chen et al., 2016a). Vertical structures of potential temperature and wind speed were realistically reproduced, with correlation coefficients between simulation and measurement results of $\sim 0.9$ over coastal, Ger-
Table 1. Configurations of WRF-Chem.

\begin{tabular}{ll}
\hline Physics & WRF options \\
\hline Microphysics & Lin scheme (Lin et al., 1983) \\
Boundary layer & YSU (Honget al., 2006) \\
Surface & Rapid Update Cycle (RUC) land surface model \\
Shortwave radiation & Goddard shortwave (Chou et al., 1998) \\
Longwave radiation & New Goddard scheme \\
Cumulus & Grell 3-D \\
Urban & 3-category UCM \\
\hline Chemistry and aerosol & Chem options \\
\hline Aerosol module & MOSAIC with 8 bins (Zaveri et al., 2008) \\
Gas-phase mechanism & CBMZ (Zaveri and Peters, 1999) \\
Photolytic rate & Fast-J photolysis scheme (Wild et al., 2000) \\
Sea-salt emission & Gong scheme (Gong, 2003) \\
\hline
\end{tabular}

man lowland (Melpitz) and northern Polish regions (Chen et al., 2016a). In line with previous studies (Xu and Penner, 2012; Li et al., 2013), the modeled AOD agreed reasonably well with the AERONET observations ( AErosol RObotic NETwork, http://aeronet.gsfc.nasa.gov, last access: 17 January 2020). The spatial distribution of AOD can be generally captured by the model $(R=0.64)$, although the model may overestimate AOD by a geometric mean bias of $70 \%$ (see Sect. S3 for details).

\subsection{North America and global simulations}

To investigate the significance of the redistribution effect in a broader spatial scale, we also conducted WRF-Chem sim- 
ulations over North America, where high concentrations of nitrate were usually observed. We focus on the period of 1017 January 2015, when strong continental outflow interacted with marine air masses over the Gulf of Mexico. The North American domain covers the US, the Gulf of Mexico and parts of the Pacific and Atlantic oceans, with a horizontal resolution of $36 \mathrm{~km}$. In addition, a 1-year simulation with global model (EMAC) was carried out for analysis of the potential impact of redistribution effect on a global scale. Although the fully dynamic mass transfer between particle sizes is not considered in EMAC (four size modes rather than eight size bins as applied in the WRF-Chem model), we adopt a parameterization derived from WRF-Chem simulations to estimate the potential impact (details given in Sect. 3.5). More details of EMAC model and its aerosol module are described in our previous work (Pozzer et al., 2012; Klingmüller et al., 2014; Pringle et al., 2010). The global simulation was run at T106L31 resolution, corresponding to a quadratic Gaussian grid of approximately $1.1^{\circ} \times 1.1^{\circ}$ (in latitude and longitude) and with 31 levels in the troposphere. The global emission inventory EDGAR (V4.3, 2010, https://edgar.jrc.ec.europa.eu, last access: 17 January 2020) was used in the North American and global simulations.

\section{Results and discussion}

\subsection{Sea-salt-induced redistribution effect}

Marine air masses frequently influence, $\sim$ up to $90 \%$ of the days in a year, central Europe (Birmili et al., 2001; Fig. 2). The interaction between anthropogenic pollutants and seasalt aerosol commonly happens in the atmosphere. In this study, we performed a series of numerical sensitivity experiments during a typical sea-salt transport event from 10 to 20 September 2013 during the HOPE-Melpitz campaign. During the campaign, central Europe was dominated by continental air masses before 15 September. Subsequently, marine air masses started traveling over land on 17 September, and sea-salt aerosol originating from the North Sea and the Baltic Sea was transported to northern Poland and dominated central Europe on 19 September (Fig. 3). Sea salt is emitted into the marine planetary boundary layer (PBL) with a mass concentration dominated by coarse particles, usually with a short lifetime and a limited transport range. Previous studies showed that the special PBL thermodynamic structure over coastal regions (Ding et al., 2004) can bring sea salt from the marine PBL to the continental free troposphere, and therefore prolonging its lifetime and favoring long-range transport (see the Fig. 11 of Chen et al., 2016a). Afterwards, the sea salt aloft could be mixed down to the surface layer by the fully developed PBL (Chen et al., 2009, 2016a) and interact with anthropogenic nitrate. Therefore, this transport mechanism broadens the sea-salt-induced redistribution effect on nitrate to a larger spatial scale.

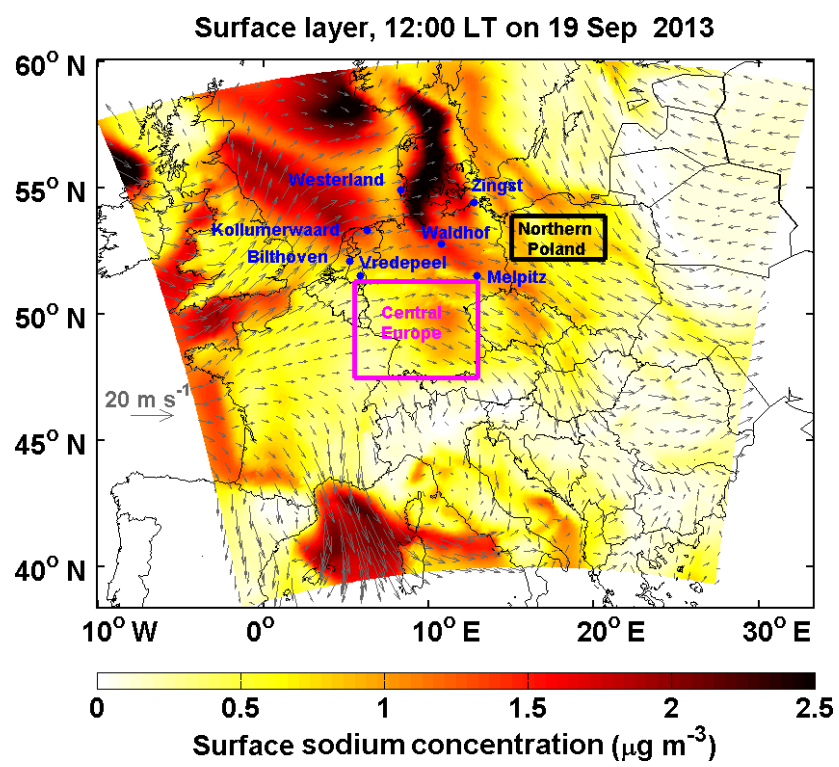

Figure 3. Surface sodium mass concentration over Europe domain at 12:00 local time (LT) on 19 September 2013. The $10 \mathrm{~m}$ wind is indicated by the gray arrows. The results are based on Case_SeasaltOn. Westerland, Waldhof, Zingst, Bilthoven, Kollumerwaard, Vredepeel, Melpitz, central Europe and northern Poland regions are marked.

As shown in Fig. 4a and b, the Case_SeasaltOn simulation successfully reproduces the redistribution effect of nitrate when the dominating air mass changed from a continental to marine type at the central Europe background site Melpitz. Measurements and model results both show an $\sim 10$ times increase of sodium concentration $\left(\left[\mathrm{Na}^{+}\right]\right.$, indicator of sea-salt aerosol) in the coarse mode when marine air masses approached (Fig. S4). While the nitrate mass fraction in the coarse mode was enhanced by a factor of $\sim 5.5$, its concentration $\left(\left[\mathrm{NO}_{3}^{-}\right]\right)$in the fine mode was lowered by $\sim 20 \%$ (Fig. 4b). A clear redistribution of particulate nitrate from fine to coarse mode is found when introducing sea salt in Case_SeasaltOn, with negligible changes in other particulate species except sea salt (Fig. 2). Conversely, without introducing sea-salt aerosol, Case_SeasaltOff did not capture the redistribution effect, and the nitrate mass in the fine mode $(\sim 97 \%)$ dominated in both continental and marine air masses (Fig. 4c).

\subsection{Moderation of nitrate cooling by the redistribution effect}

Figure 5 shows the strong impact of the redistribution effect on nitrate cooling when a marine air mass transported further inland and predominated over Europe on 19 September. Although sea-salt aerosol leads to an overall enhancement of nitrate column loading ( $\sim 1 \mathrm{mg} \mathrm{m}^{-2}$, Fig. S5) compared to Case_SeasaltOff, the nitrate-associated aerosol optical depth $\left(\mathrm{AOD}_{\text {nitrate }}\right)$ decreases significantly over the rel- 

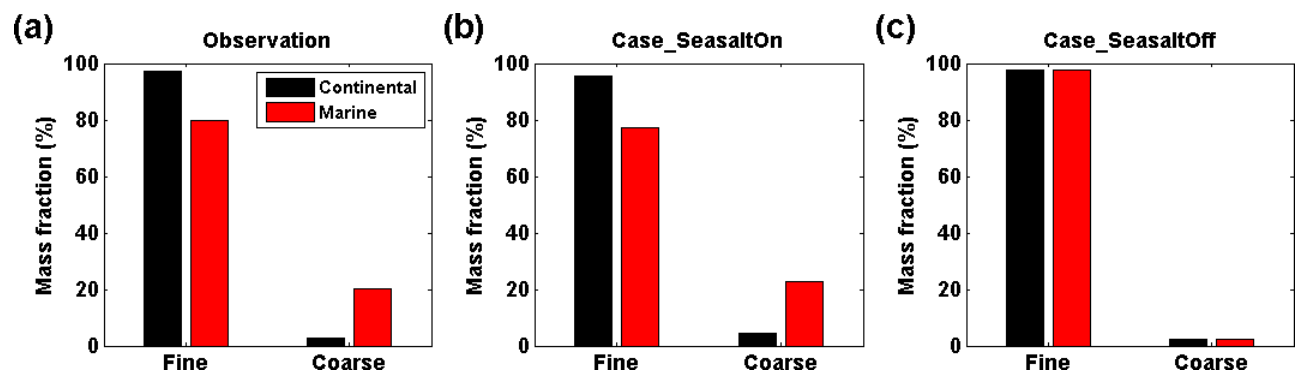

Figure 4. Observed and simulated mass fraction of particulate nitrate in fine and coarse modes at Melpitz, Germany. (a) Observation based on the Berner impactor measurements. (b) WRF-Chem Case_SeasaltOn simulation, i.e., with sea-salt emission. (c) WRF-Chem Case_SeasaltOff simulation, i.e., without sea-salt emission. The results are grouped into continental (black bar) and marine (red bar) air mass types. According to the size-cuts of the Berner impactor, the size ranges of the fine- and coarse-mode particles are defined as $\mathrm{PM}_{1.2}$ (particles with an aerodynamic diameter smaller than $1.2 \mu \mathrm{m}$ ) and $\mathrm{PM}_{1.2-10}$ (particles with an aerodynamic diameter larger than $1.2 \mu \mathrm{m}$ and smaller than $10 \mu \mathrm{m})$, respectively.

atively polluted continental regions (Fig. 5a), leading to a strongly weakened cooling effect of nitrate in those regions (positive change in $\mathrm{DRF}_{\text {nitrate }}$ in Fig. 5b). We find that the regions of reduced $\mathrm{AOD}_{\text {nitrate }}$ co-locate with the regions of reduced fine mode $\left[\mathrm{NO}_{3}^{-}\right]$(bluish colored areas in Fig. 5a and c). Over a large area of the European continent, the redistribution effect shifts the nitrate PMSD from the fine to the coarse mode (Fig. 5c, d), resulting in much less efficient light scattering of nitrate aerosol with a reduced cooling effect. The box with a solid black frame in Fig. 5 marks a region in northern Poland, where sea-salt aerosol strongly interacted with anthropogenic precursors of nitrate during the studied sea-salt event. In this region, the redistribution effect leads to a decrease in column nitrate loading in the fine mode by $\sim 2.9 \mathrm{mg} \mathrm{m}^{-2}$ (Fig. 5c) accompanied by an increase of $\sim 3.7 \mathrm{mg} \mathrm{m}^{-2}$ in the coarse mode due to the massenhancement effect (Fig. 5d). Consequently, anthropogenic $\mathrm{AOD}_{\text {nitrate }}$ is significantly reduced by up to $\sim 30 \%$ with an average reduction of $\sim 22 \%(\sim 0.05$ in absolute AOD value, Fig. 5a), despite a $\sim 0.8 \mathrm{mg} \mathrm{m}^{-2}$ net increase in total nitrate loading. This results in a $5 \%-70 \%$ reduction in nitrate cooling, on average by $\sim 26 \%$ (Fig. $5 b$ ). Our results demonstrate that the sea-salt-induced redistribution effect overwhelms the mass-enhancement effect over polluted regions, thus moderating the anthropogenic nitrate cooling.

The resulting decrease of nitrate cooling is nonlinear with respect to the sea-salt aerosol loading due to the competition between sea-salt-induced mass-enhancement effect and redistribution effect. To investigate the net impact of this competition, we performed a series of sensitivity simulations with different sea-salt aerosol emission scaling factors $(0$, $0.5,1,2,3,4,5,6,8$ and 10 , the ones with scaling factors of 0 and 1 being our Case_SeasaltOff and Case_SeasaltOn, respectively). As a surrogate of aerosol DRF, the AOD of nitrate and sea-salt aerosol was calculated offline based on the simulated PMSD (see "Data and methods"). Over the region in northern Poland (box with solid frame in Fig. 5), total $\left[\mathrm{NO}_{3}^{-}\right]$(green dashed line in Fig. 6a) increased contin- uously as a function of $\left[\mathrm{Na}^{+}\right]$, which is in line with previous estimates and clearly shows the mass-enhancement effect (Liao and Seinfeld, 2005). However, the redistribution effect overwhelms the mass-enhancement effect in this region, and the $\mathrm{AOD}_{\text {nitrate }}$ drops significantly by $\sim 29 \%$ (red solid line in Fig. 6a) when the scaling factor of sea-salt aerosol is 1 (Case_SeasaltOn). Note that this is slightly higher than the average $\sim 22 \%$ from the online calculation, due to the difference in aerosol mixing state, i.e., internal mixing of aerosol compositions in the online calculation and external mixing in the off-line calculation. The reduction in $\mathrm{AOD}_{\text {nitrate }}$ reaches a maximum of $\sim 50 \%(\sim 0.09$ in absolute AOD value) when $\left[\mathrm{Na}^{+}\right]$is $\sim 2.5 \mu \mathrm{g} \mathrm{m}^{-3}$ or higher, which is a level of sea-salt aerosol that has been often observed in central Europe (Fig. 6c; Gustafsson and Franzén, 2000; Neumann et al., 2016; Gantt et al., 2015). A similar net reduction in $\mathrm{AOD}_{\text {nitrate }}$ is also found for central Europe (marked in Fig. 3), where the overall moderation is $\sim 13 \%$ compared to Case_SeasaltOff (Fig. S6a). To further demonstrate the influence of the redistribution effect on nitrate cooling, we calculate the $\triangle \mathrm{AOD}_{\text {nitrate }}$ by reallocating nitrate mass into different size bins according to the normalized nitrate PMSD simulated in Case_SeasaltOff, i.e., by neglecting the redistribution effect $\left(\triangle \mathrm{AOD}_{\text {nitrate }}^{*}\right.$, pink dashed line in Fig. 6a). A distinct opposite trend, of increasing $\mathrm{AOD}_{\text {nitrate }}^{*}$ with increasing $\left[\mathrm{NO}_{3}^{-}\right]$(green dashed line), would result when the redistribution effect was neglected. For example, instead of a decrease by $29 \%$, the $\mathrm{AOD}_{\text {nitrate }}^{*}$ over the region of northern Poland increases by $\sim 8 \%$ from the Case_SeasaltOff to Case_SeasaltOn simulation.

It is noteworthy that the increasing rate of $\left[\mathrm{NO}_{3}^{-}\right]$decreases as $\left[\mathrm{Na}^{+}\right]$further increases. There is even a slight decrease of $\left[\mathrm{NO}_{3}^{-}\right]$when $\left[\mathrm{Na}^{+}\right]$exceeds $\sim 5 \mu \mathrm{g} \mathrm{m}^{-3}$ (Fig. 6a). This is mostly due to the consumption of nitrate precursor and stronger deposition of particulate nitrate by redistribution toward larger particles sizes and, thus, shorter lifetimes. The lifetime of nitrate particles can be shortened from about a week to $1 \mathrm{~d}$ by shifting from the fine to the coarse 
(a)

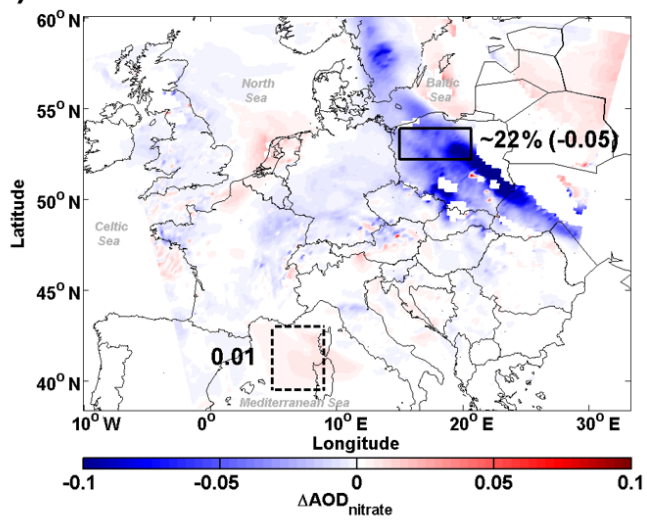

(c)

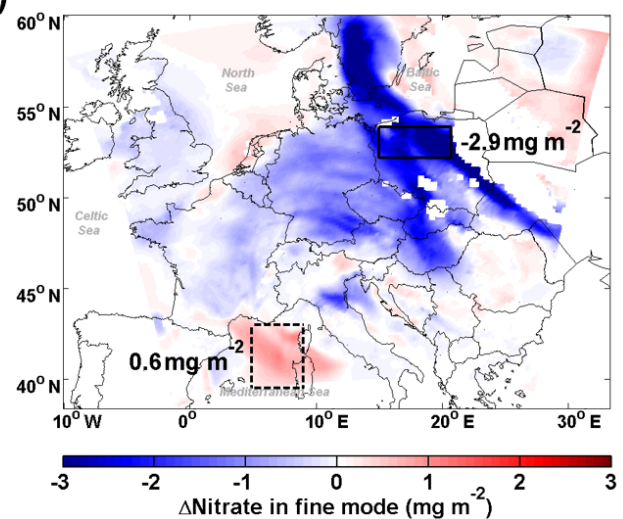

(b)

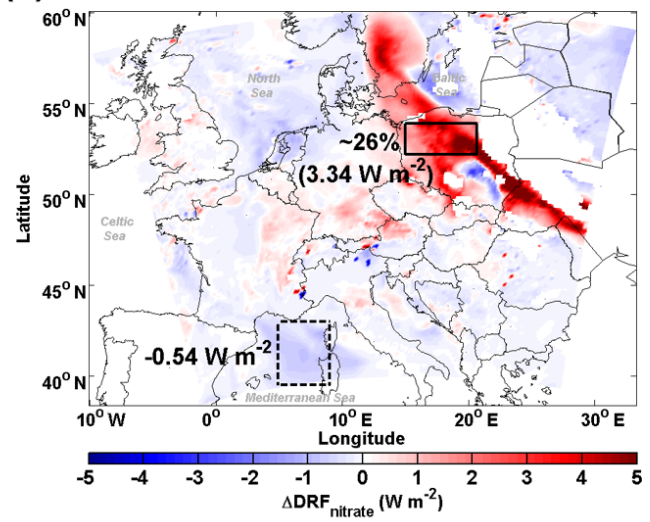

(d)

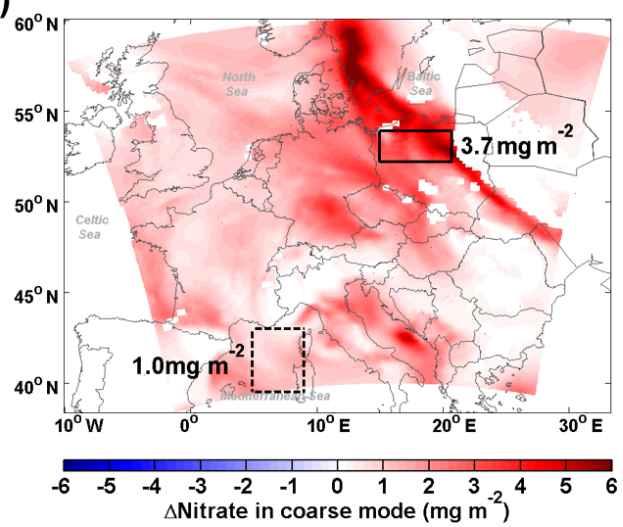

Figure 5. Influence of sea salt on the abundance and direct radiative forcing of nitrate. (a) Differences (Case_SeasaltOn - Case_SeasaltOff) between simulations with and without sea-salt emission in aerosol optical depth $\left(\Delta \mathrm{AOD}_{\text {nitrate }}\right),(\mathbf{b})$ direct radiative forcing $(\Delta \mathrm{DRF}$ nitrate), and column loading of nitrate ( $\Delta$ Nitrate) for the (c) fine- and (d) coarse-mode particles, during daytime, i.e., 07:00-16:00 local time (LT) on 19 September 2013. The northern Poland and Mediterranean regions are marked by boxes with solid and dashed black frames, respectively.

mode (Croft et al., 2014; Chen et al., 2016b) further moderating the nitrate cooling effect. Moreover, coarse-mode nitrate associated with highly hygroscopic sea salt enhances its water uptake (Chen et al., 2018a) and cloud condensation nuclei activation (Xu and Penner, 2012; Wang and Chen, 2019), increasing its deposition and scavenging rate Itahashi et al. (2016) reported that oxidized nitrogen deposition can be enhanced by 1.6-2.2 times over ocean regions in East Asia by including sea-salt-associated nitrate. Liao and Seinfeld (2005) implied a similar enhancement for sulfate deposition associated with sea salt and dust, which resulted in a decrease in sulfate concentrations in downwind regions. Our study implies the enhancement of nitrate deposition. As one can see in Fig. 6a, nitrate concentration (green dashed line) firstly increases with increasing sea salt and then slightly declines when the amount of sea salt (represented by sodium) exceeds a certain level. An inflection point is observed when the sodium concentration approached $5.5 \mu \mathrm{g} \mathrm{m}^{-3}$ (sea-salt emission factor of 8); the nitrate starts to decrease as sodium further increases (sea-salt emission factor of 10). The enhancement of nitrate deposition should be the reason of this phenomenon. To demonstrate this, we conducted a sensitivity simulation with aerosol dry deposition turned off. We found that nitrate concentration kept increasing from 10.91 to $11.02 \mu \mathrm{g} \mathrm{m}^{-3}$ when sea-salt emission factors increased from 8 to 10 , instead of showing a decreasing trend as in the simulations with aerosol dry deposition turned on. This indicates an enhanced deposition of nitrate by interaction with sea salt, which shortens nitrate lifetime and can further reduce nitrate cooling.

\subsection{Competition between redistribution effect and mass-enhancement effect}

As a result of competition between the sea-salt-induced redistribution effect and mass-enhancement effect, a clear spatial inhomogeneity can be found in Fig. 5. The redistribution effect decreases $\mathrm{AOD}_{\text {nitrate }}$ over the polluted continental regions, while the mass-enhancement effect increases $\mathrm{AOD}_{\text {nitrate }}$ mostly over marine areas (Fig. 5a), although the absolute enhancement is rather small due to the low $\left[\mathrm{NO}_{3}^{-}\right]$in this environment. For example, over the Mediterranean Sea 
(a)

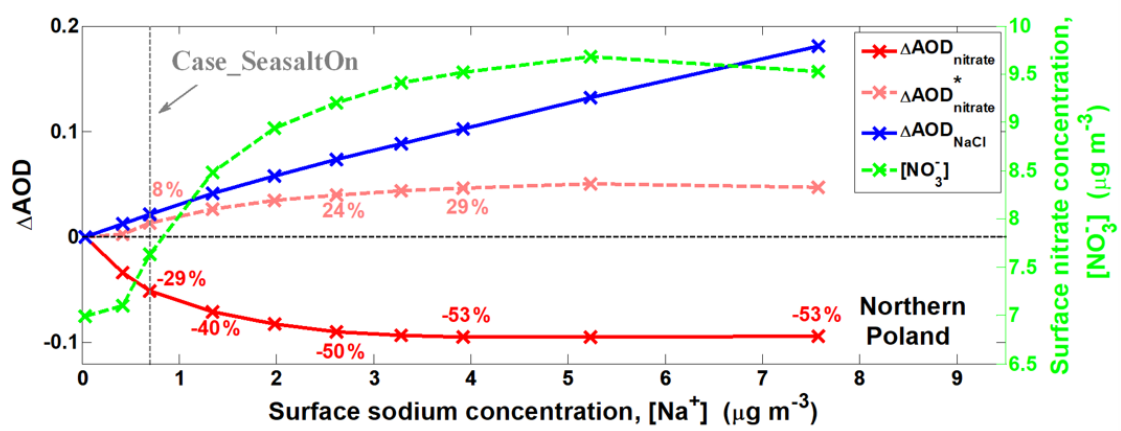

(b)

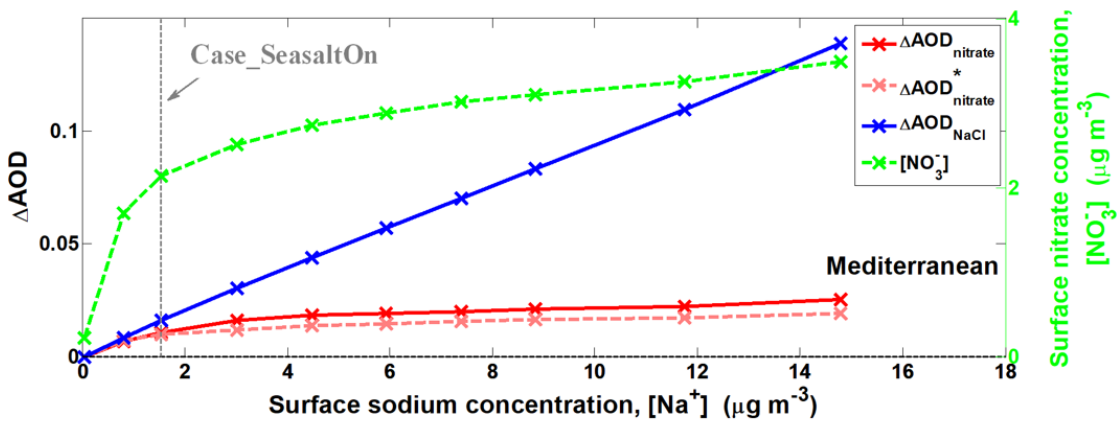

(c)

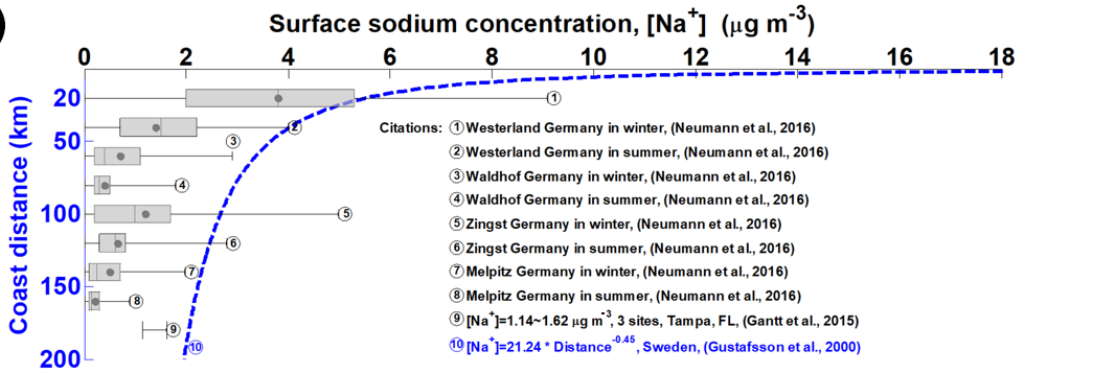

Figure 6. Sensitivity of aerosol optical depth $(\triangle \mathrm{AOD})$ as a function of sodium mass concentration $\left(\left[\mathrm{Na}^{+}\right]\right)$. Differences between Case_SeasaltOff and sensitivity cases (sea-salt emission with different scaling factors) for different aerosol components, i.e., nitrate $(\triangle \mathrm{AOD}$ nitrate $)$ and sea salt $\left(\triangle \mathrm{AOD} \mathrm{DaCl}_{\mathrm{Na}}\right): \triangle \mathrm{AOD}$ (sensitivity case - Case_SeasaltOff) versus $\left[\mathrm{Na}^{+}\right]$over northern Poland (a) and Mediterranean regions (b), respectively. The model results shown here are averages over a sea-salt event during daytime (07:00-16:00 LT) on 19 September 2013. The results of surface $\left[\mathrm{NO}_{3}^{-}\right]$are indicated by the dashed green line. Here, the Case_SeasaltOff is the reference case and Case_SeasaltOn is marked. Note: $\triangle \mathrm{AOD}_{\text {nitrate }}^{*}$ (dashed pink line) indicates the $\triangle \mathrm{AOD}$ of nitrate calculated by reallocating nitrate mass into different size bins according to the normalized nitrate particle mass size distribution simulated in Case_SeasaltOff (i.e., without redistribution effect). (c) The measured $\left[\mathrm{Na}^{+}\right]$at different sites over Sweden as a function of coast distance, as well as in Germany (marked in Fig. 3) and the US. The box-and-whisker plots of the references marked (1)-(8) indicate the median, mean (black dot), 25th percentile, 75th percentile, maximum and minimum. The error bar of reference no. (9) indicates the range. The dashed blue line of reference no. (10) indicates the statistically empirical function of $\left[\mathrm{Na}^{+}\right]$with distance from coast, based on the network measurements of 16 sites in Sweden.

(marked by the box with a dashed black frame in Fig. 5), the $\mathrm{AOD}_{\text {nitrate }}$ increases by $\sim 0.01$ and the cooling effect of nitrate is amplified by $\sim 0.54 \mathrm{~W} \mathrm{~m}^{-2}$ (negligible without introducing sea-salt aerosol). A sensitivity study also shows a monotonic increase of $\mathrm{AOD}_{\text {nitrate }}$ with $\left[\mathrm{Na}^{+}\right]$over the Mediterranean Sea (Fig. 6b), indicating a dominant role of the mass-enhancement effect over regions with limited anthropogenic influence.

Thus, abundant sea-salt aerosol and pre-existing finemode nitrate (as if there was no sea-salt aerosol influence in Case_SeasaltOff) favor an efficient redistribution effect that reduces $\mathrm{AOD}_{\text {nitrate }}$ and moderates nitrate cooling. To compare the relative importance of the sea-salt-induced redistribution effect and mass-enhancement effect on anthropogenic nitrate cooling, we conducted statistical analysis of the molar ratio between fine nitrate in Case_SeasaltOff and total sodium in Case_SeasaltOn (called RNS, RNS $=\left[\mathrm{NO}_{3}^{-}\right] /\left[\mathrm{Na}^{+}\right]$in $\mathrm{mol} \mathrm{mol}^{-1}$ ) with relation to the percentage change in nitrate $\mathrm{AOD}$ (surrogate of $\mathrm{DRF}_{\text {nitrate }}$ ) between the two cases, i.e., ( $\mathrm{AOD}_{\text {nitrate }}$ Case_SeasaltOn - 


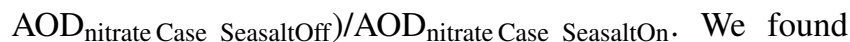
that the redistribution effect tends to be strong enough to overwhelm the mass-enhancement effect when the RNS value is in the range of about 1 to 30 , corresponding to $\sim 70 \%$ of the data points in the European domain, as detailed in the Supplement (Fig. 7c and Sect. S4). Note that only the surface concentrations were used for calculating the RNS, because fine-mode ammonium nitrate is mostly limited in the surface layer because emissions of $\mathrm{NH}_{3}$ are in the surface layer. The sea salt (or sodium) aloft during the transport process (as discussed in Sect. 3.1) did not exert the redistribution effect before being mixed down to the surface layer, and it should not be included in the analysis. Therefore, we carried out a statistical analysis with surface nitrate and sodium concentrations to draw a more robust conclusion. When the redistribution effect is sufficiently strong, the net reduction in $\mathrm{AOD}_{\text {nitrate }}$ may even counteract the AOD enhancement contributed by the additional sea-salt aerosol loading and lead to an overall reduction in total AOD in many regions in Europe (Fig. S6b and Sect. S5).

\subsection{The redistribution effect over Europe}

Due to the frequent interactions between sea-salt aerosol and polluted air masses (Myhre et al., 2006; Xu and Penner, 2012), the moderation of nitrate cooling is expected to be common over Europe, where the lower atmosphere is characterized by RNS values between 1 and 30 (Fig. 7). As discussed above (Figs. 6a and S6), considerable moderation is expected over inland and central Europe, where $\left[\mathrm{Na}^{+}\right]>2.5 \mu \mathrm{g} \mathrm{m}^{-3}$ is observed frequently (Gustafsson and Franzén, 2000, also see Fig. 6c). Such moderation could be even more relevant over coastal and continental outflow regions of North America and Southeast Asia (discussed in the next section), where high loadings of nitrate were observed and found to be significantly associated with sea-salt aerosol (30\%-90\% of total nitrate) (Xu and Penner, 2012).

To quantify the possible overestimation of nitrate radiative forcing when only the sea-salt-induced mass-enhancement effect was treated but not the redistribution effect, a similar statistical analysis (Fig. 7a) is conducted for the percentage change in nitrate $\mathrm{AOD}$ between the $\mathrm{AOD}_{\text {nitrate }}$ in Case_SeasaltOn and the corresponding $\mathrm{AOD}_{\text {nitrate }}^{*}$ i.e., $\left(\mathrm{AOD}_{\text {nitrate }}-\mathrm{AOD}_{\text {nitrate }}^{*}\right) / \mathrm{AOD}_{\text {nitrate }}$. As described before, $\mathrm{AOD}_{\text {nitrate }}$ stands for the case where both massenhancement and redistribution effects have been accounted for Case_SeasaltOn, while only the mass-enhancement effect is accounted for in $\mathrm{AOD}_{\text {nitrate }}^{*}$. Figure. $7 \mathrm{~b}$ shows that the $\mathrm{AOD}_{\text {nitrate }}^{*}$ could increase by 5\%-30\% when introducing sea salt and only the mass-enhancement effect is considered. Conversely, the statistics show that the redistribution effect tends to significantly reduce the nitrate AOD by $10 \%-$ $20 \%$ when there is abundant sea salt interacting with anthropogenic nitrate (RNS $<\sim 30$, Fig. 7a). Note that this estimation of percentage reduction in $\mathrm{AOD}_{\text {nitrate }}$ is robust (may be (a)

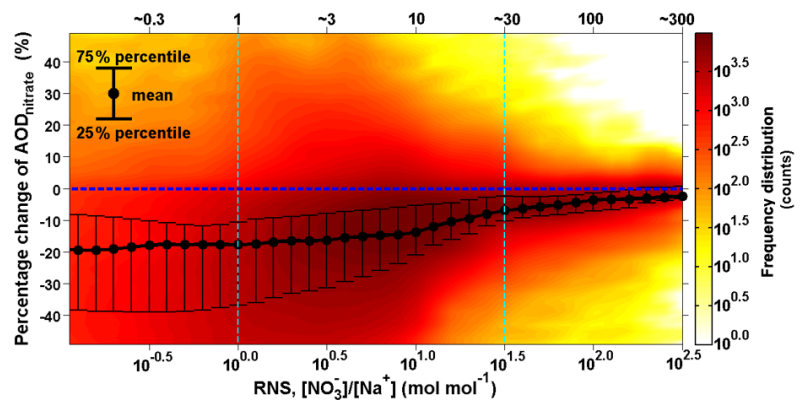

(b)

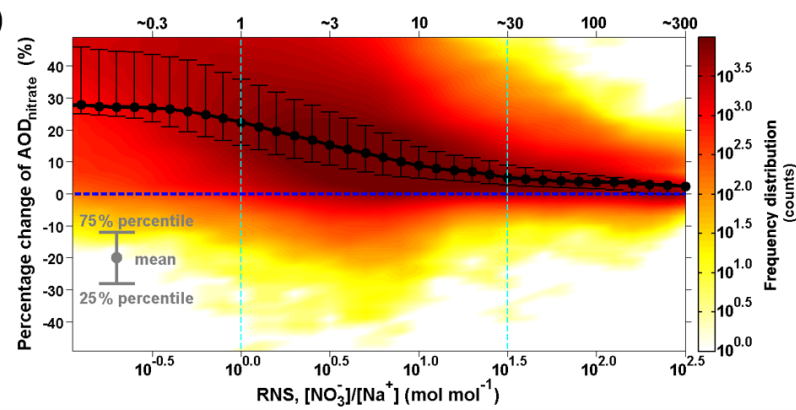

(c)

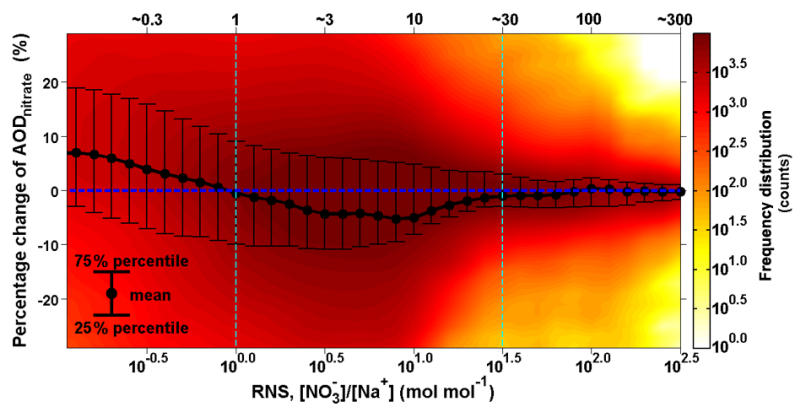

Figure 7. Intensity of the redistribution effect as a function of molar ratio between surface fine nitrate and total sodium (RNS) over the European domain. (a) The intensity of the redistribution effect is calculated as the difference in percentage between $\mathrm{AOD}_{\text {nitrate }}$ and $\mathrm{AOD}_{\text {nitrate }}^{*}$ in Case_SeasaltOn; (b) the intensity of mass-enhancement effect. The black dots indicate the mean values; the upper and lower error bars indicate the 75th and 25th percentiles, respectively; (c) the net effect of mass-enhancement and redistribution effects; the color indicates the frequency distribution (i.e., how many counts) of the hourly model results over the entire European domain during 16-20 September 2013. The coverage of model results between the two dashed light-blue lines is $\sim 70 \%$.

slightly conservative), despite the overestimation of particulate nitrate over Europe (Sect. S6). The uncertainty in deposition parameterizations could be one reason of this overestimation, as suggested by the overestimation of sea-salt particles as well (Chen et al., 2016a) and the underestimation of nitrogen deposition over Europe in many models (Vivanco et al., 2017). The upper limit of our result is comparable to a previous estimate of $25 \%$ reduction in $\mathrm{AOD}_{\text {nitrate }}$ by sea-salt aerosol on a global scale by Myhre et al. (2006). They evaluated a similar redistribution effect of sea-salt aerosol. But the simplifications of the mass transfer between fine and coarse 
modes may lead to overestimation of the reduction (Sect. S1). The redistribution effect becomes rather weak (limited within $10 \%$ ) as RNS further increased (RNS $>\sim 30$ ) when marine air masses are transported further inland.

\subsection{The redistribution effect over North America and on a global scale}

An additional simulation over North America confirms our findings. Similarly, as over Europe, the sea-salt-induced redistribution effect predominates and reduces $\mathrm{AOD}_{\text {nitrate }}$ over industrialized and outflow regions of the North American domain (Fig. 8). Generally, a similar reduction in $\mathrm{AOD}_{\text {nitrate }}$ is found over North America due to the sea-salt-induced redistribution effect. A monotonous decrease (increase) of column fine (coarse) nitrate loading is observed all over North America and oceanic regions (Fig. 8c and d). This sea-salt-induced redistribution effect overwhelms the mass-enhancement effect over most regions and, thus, reduces $\mathrm{AOD}_{\text {nitrate }}$ (Fig. 8a) and cooling effect of nitrate especially over the Gulf of Mexico (Fig. 8b), although the total nitrate column loading increases significantly (Fig. S7). This is because the high concentration of nitrate in the continental outflow from North America and Central America strongly interacts with sea salt over the Gulf of Mexico (Xu and Penner, 2012).

The statistical analysis of the redistribution effect over North America (Fig. 9a) shows a similar pattern as over Europe (Fig. 7a), and a first-order approximation $\left(R^{2}>90 \%\right)$ is derived from the European and North American results of the WRF-Chem model to parameterize the relationship between RNS and the changes in $\mathrm{AOD}_{\text {nitrate }}$ associated with the redistribution effect (Fig. 9b). In general, the impact of the redistribution effect on $\mathrm{AOD}_{\text {nitrate }}$ decreases as RNS increases. Only considering the mass-enhancement effect but ignoring the redistribution effect may lead to an overestimation of $\mathrm{AOD}_{\text {nitrate }}$ by about $20 \%$ when RNS $<1$, by about $10 \%-20 \%$ when $1 \leq \mathrm{RNS} \leq 30$ and by less than $\sim 10 \%$ when RNS $>30$.

On a global scale, the potential influence of the redistribution effect on $\mathrm{AOD}_{\text {nitrate }}$ is estimated by using the above first-order approximation combined with a 1-year RNS simulation with the EMAC (Klingmüller et al., 2014; Pringle et al., 2010) chemistry-climate model (Fig. 10). The global distributions of percentage changes in $\mathrm{AOD}_{\text {nitrate }}$ and surface nitrate concentration are given in Fig. S8. In line with the WRF-Chem results, a significant redistribution effect is expected over North America and Europe, especially over the coastal regions with high nitrate loading and RNS values around 1 (Fig. 10b). As shown in Fig. 10c, the impact over Europe is stronger than over North America. The oceanic influence dominates over western Europe, whereas over North America the predominantly more continental air masses (Kottek et al., 2006) may be a possible reason of this. It leads to less interactions of sea salt with anthropogenic nitrate in North America and more significant reduction in
$\mathrm{AOD}_{\text {nitrate }}$ over Europe. This result is consistent with a previous study (Myhre et al., 2006). Nevertheless, it is still possible that sea salt is transported (May et al., 2018) further inland over North America and impacts $\mathrm{AOD}_{\text {nitrate }}$ there. The coastal and offshore regions of Asia with $11 \leq \mathrm{RNS} \leq 30$ may experience strong reductions of $\mathrm{AOD}_{\text {nitrate, }}$ where the redistribution effect is expected to overwhelm the massenhancement effect, such as coastal and outflow regions of China. The influence of sea-salt aerosol becomes negligible over inland Asia where the marine air mass influence is small (RNS $>30$ ). For the open sea regions with RNS $<0.01$ (white background), the nitrate climate effect is not important, due to a very limited nitrate loading contributing to $\mathrm{AOD}_{\text {nitrate }}$ (Fig. 10a).

\section{Summary and discussion}

The interaction between natural sea-salt aerosols and anthropogenic nitrate leads to the redistribution effect, which can shift the particulate nitrate from sub- to super-micron sizes. This effect lowers its mass light extinction efficiency and shortens its lifetime. This redistribution effect can significantly moderate nitrate cooling.

The interaction between natural sea-salt aerosols and anthropogenic nitrate happens frequently over Europe (up to $90 \%$ of the days in a year). We performed a series of sensitivity studies during a typical sea-salt event over Europe, using the WRF-Chem model with a fully dynamic aerosol mass transfer treatment coupled online. The redistribution effect of nitrate is observed by field measurements and well captured by the Case_SeasaltOn simulation. Over the highly polluted northern Poland region, our sensitivity modeling results show that the redistribution effect can reduce $\mathrm{AOD}_{\text {nitrate }}$ by about $20 \%-30 \%$, or even up to $\sim 50 \%$ when the sea-salt event is sufficiently strong. Conversely, if we only consider the increase of nitrate mass by introducing sea salt (massenhancement effect) and ignore the redistribution effect, nitrate AOD could increase by $\sim 8 \%$ or even up to $\sim 30 \%$ in a strong sea-salt event. We propose a single parameter, RNS $\left(\left[\mathrm{NO}_{3}^{-}\right] /\left[\mathrm{Na}^{+}\right]\right.$in $\left.\mathrm{mol} \mathrm{mol}^{-1}\right)$, to describe the competition between the sea-salt-induced redistribution effect and the mass-enhancement effect. In general, (1) the sea-salt-induced mass-enhancement effect is dominant over oceanic regions and tends to increase $\mathrm{AOD}_{\text {nitrate }}$; the dominance of massenhancement effect could take place when RNS is lower than $1 ;$ (2) the sea-salt-induced redistribution effect on nitrate PMSD can decrease $\mathrm{AOD}_{\text {nitrate }}$ by about $10 \%-20 \%$ and overwhelm the mass-enhancement effect, resulting in a net reduction in $\mathrm{AOD}_{\text {nitrate }}$; this could take place when RNS is in the range between 1 and 30; and (3) the influence of seasalt aerosol is not significant when RNS is higher than 30 . These findings are further confirmed by the sensitivity simulations over North America. The impact of the redistribution effect on a global scale is estimated using global simu- 
(a)

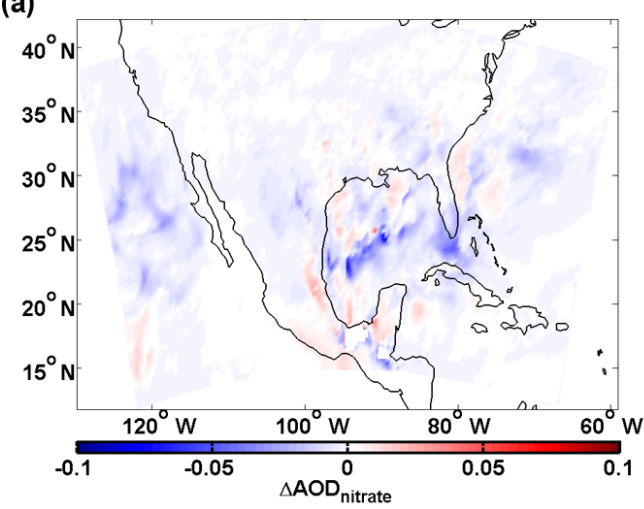

(c)

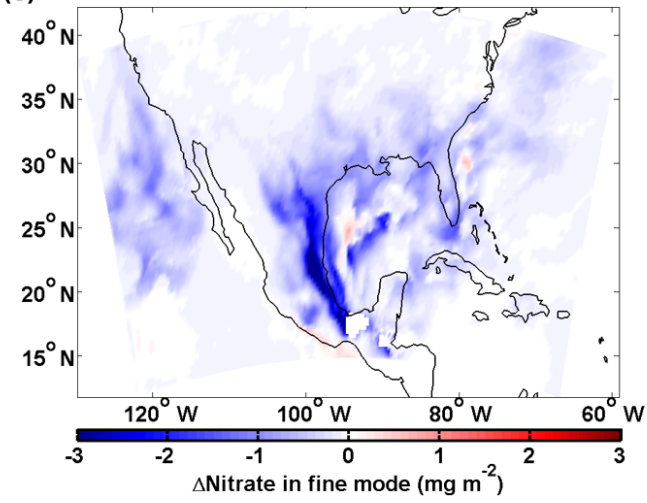

(b)

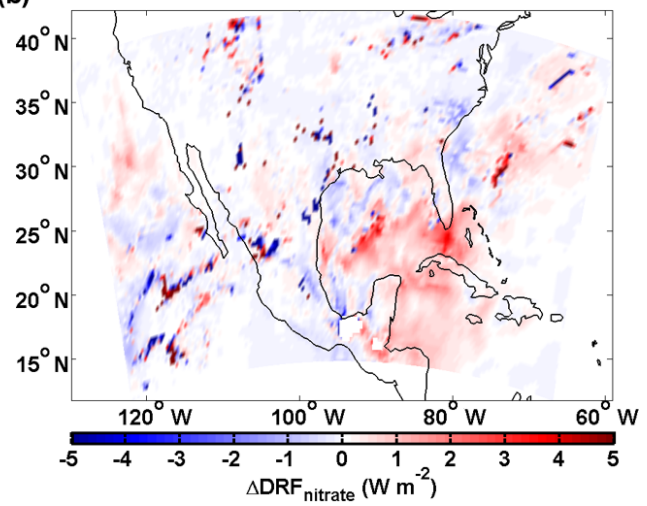

(d)

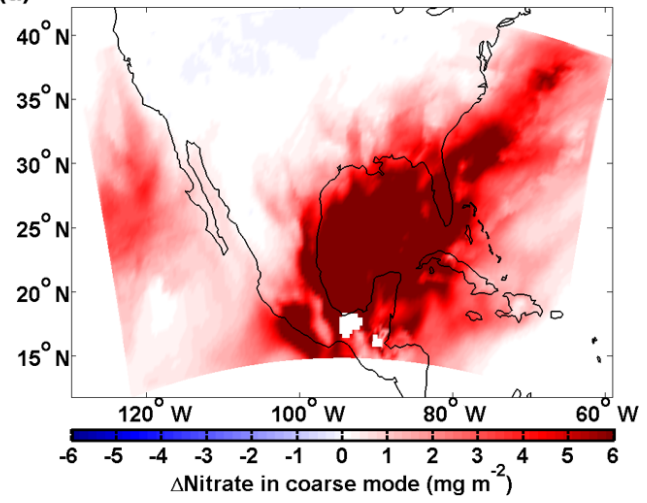

Figure 8. Influence of sea-salt aerosol on the abundance and direct radiative forcing of nitrate (similar to Fig. 5). (a) Differences (Case_ SeasaltOn - Case_SeasaltOff) between simulations with and without sea-salt emission in aerosol optical depth $\left(\triangle \mathrm{AOD}_{\text {nitrate }}\right),(\mathbf{b})$ direct radiative forcing $\left(\triangle \mathrm{DRF} \mathrm{Fitrate}_{\mathrm{n}}\right)$ and column loading of nitrate ( $\triangle$ Nitrate) for the (c) fine- and (d) coarse-mode particles. The modeled results shown here are averaged during daytime over the North American domain, i.e., 16:00-22:00 (UTC) on 10-17 January 2015.

lation of RNS. A significant redistribution effect is expected over Europe, the Gulf of Mexico, Eastern Asia and coastal and offshore regions worldwide, resulting in a reduction in $\mathrm{AOD}_{\text {nitrate }}$ by about $10 \%-20 \%$. This study demonstrates the suppression of AOD and DRF of particulate nitrate by the redistribution effect. In addition, the redistribution effect may also reduce the number of cloud condensation nuclei $(\mathrm{CCN})$ by lowering the nitrate concentration in fine particles, which are the main contributors to $\mathrm{CCN}$ number. The hygroscopicity of coarse sea-salt particles could also be reduced by associating with nitrate, which might suppress cloud droplet activation (Xu and Penner, 2012). Further studies are needed to investigate the influences of the redistribution effect on aerosol-cloud interactions and indirect radiative forcing.

\section{Implication}

This study highlights the impact of the redistribution effect on moderating nitrate cooling and altering the nitrogen deposition efficiency by interacting with natural sea-salt aerosols (Fig. 1). A similar redistribution effect may apply to the heterogeneous reaction and consumption of gaseous organic compounds and sulfuric and nitric acids on natural desert dust (Usher et al., 2003; Ponczek and George, 2018; Dupart et al., 2012; Ravishankara, 1997), although nonvolatile particulate sulfate does not shift from fine to the coarse-mode aerosols. Uptake of acids by dust particles can shorten their lifetimes and reduce their radiative forcing (Liao and Seinfeld, 2005; Harris et al., 2013; Karydis et al., 2016; Abdelkader et al., 2015), which could be significant over inland areas where sea-salt aerosol is lacking. All these previous studies imply the possibility that natural particles (sea-salt aerosol and very likely dust as well) moderate the DRF of anthropogenic aerosols and alter the nitrogen and sulfur deposition efficiency. We highlight the importance of further study of the interactions between natural and anthropogenic aerosols. More comprehensive modeling studies with fully dynamic aerosol mass transfer treatments are needed for improving the assessment of aerosol climate effect accounting for the redistribution effect on a global scale. 

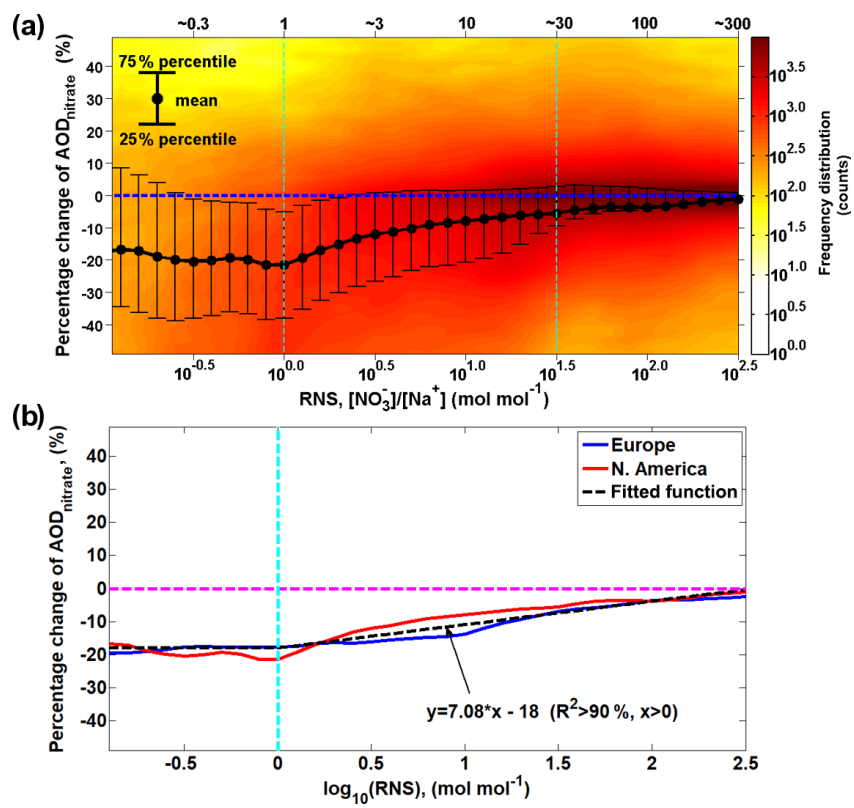

Figure 9. Intensity of redistribution effect as a function of molar ratio between surface fine nitrate and total sodium (RNS). (a) The intensity of the redistribution effect over the North American domain, similar to Fig. 7a, is calculated as the difference in percentage between $\mathrm{AOD}_{\text {nitrate }}$ and $\mathrm{AOD}_{\text {nitrate }}^{*}$ in Case_SeasaltOn. AOD $\mathrm{A}_{\text {nitrate }}^{*}$ indicates the $\mathrm{AOD}_{\text {nitrate }}$ calculated by reallocating nitrate mass into different size bins according to the normalized nitrate particle mass size distribution simulated in Case_SeasaltOff (i.e., without redistribution effect). The black dots indicate the mean values; the upper and lower error bars indicate the 75 th and 25 th percentiles, respectively. The color indicates the frequency distribution (i.e., how many counts) of the hourly model results over the entire North American domain during 10-17 January 2015. (b) The median possibility of the percentage change in $\mathrm{AOD}_{\text {nitrate }}$ as a function (first-order approximation) of RNS.

Data availability. WRF-Chem model code is openly available from https://www2.acom.ucar.edu (NCAR/UCAR, 2020). FINN fire emissions is openly available for download from http://bai.acom.ucar.edu/Data/fire/ (Wiedinmyer et al., 2011). NCEP FNL operational model global tropospheric analyses (ds083.2) is openly available from https://rda.ucar.edu/data/ds083. 2/ (NCEP/National Weather Service/NOAA/U.S. Department of Commerce, 2000), and sea surface temperature data is openly available from https://polar.ncep.noaa.gov/sst/ (NCEP SST, 2019). AERONET and aerosol observational datasets are openly available for download from the websites https://aeronet.gsfc.nasa.gov/ (AERONET, 2020) and http://ebas.nilu.no/default.aspx (EBAS, 2020). The European emission inventory is available from the AQMEII project (http://aqmeii.jrc.ec.europa.eu/, AQMEII, 2020) and EUCAARI project (https://www.atm.helsinki.fi/eucaari/?q= node/3, EUCAARI, 2020). The global emission inventory is available from the EDGAR project (http://edgar.jrc.ec.europa.eu, EDGAR, 2020). The results of the EMAC global model are available from https://doi.org/10.17635/lancaster/researchdata/297 (Chen et al., 2020). (a)

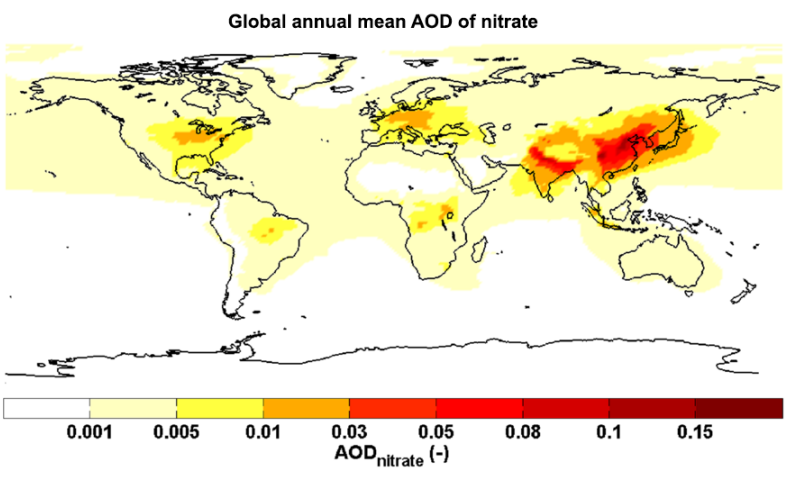

(b)

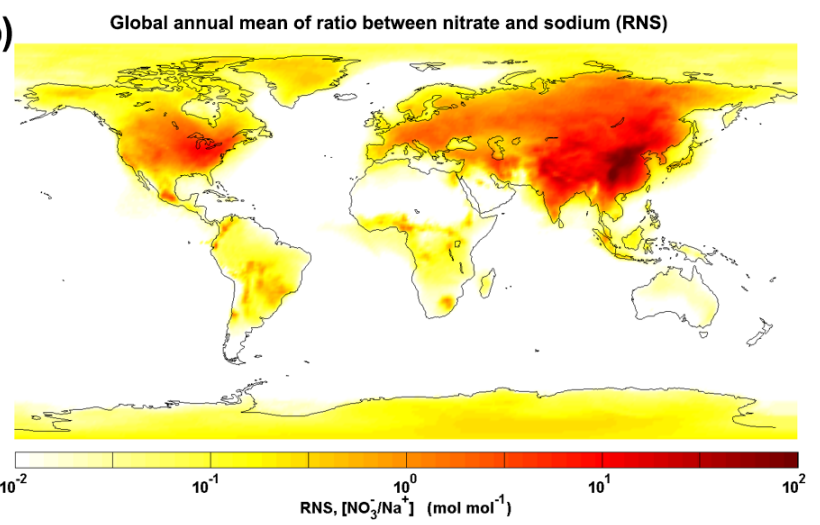

(c)

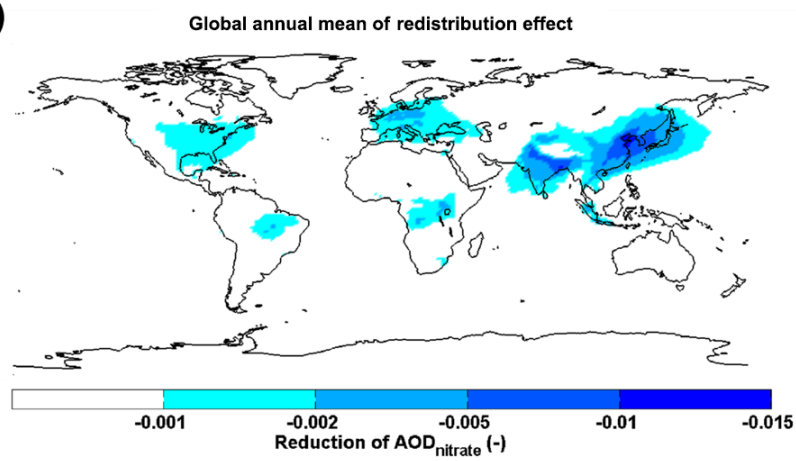

Figure 10. The global distribution of annual mean $\mathrm{AOD}_{\text {nitrate }}$ (a), RNS (b) and reduction in $\mathrm{AOD}_{\text {nitrate }}$ associated with the redistribution effect (c). The results of (a) and (b) are simulated with the EMAC model; the results of (c) are estimated from the first-order approximation in Fig. 9b.

Supplement. The supplement related to this article is available online at: https://doi.org/10.5194/acp-20-771-2020-supplement.

Author contributions. YaC led the study. YaC and $\mathrm{YiC}$ conceived and designed the study. YiC performed the WRF-Chem model simulations and processed the data. NM supported the optical calculation. $\mathrm{CW}$ supported the kinetic part of the model simulation and result analyses. AP and JL provided the EMAC global simulation. GS carried out the aerosol chemical composition observations at Melpitz. YiC, YaC and HS interpreted the results. All co-authors 
discussed the results. YiC and $\mathrm{YaC}$ wrote the article with inputs from all co-authors.

Competing interests. The authors declare that they have no conflict of interest.

Acknowledgements. We thank Konrad Müller (TROPOS) for his contribution to the aerosol composition measurements. Yafang Cheng would also like to thank the Minerva Program of MPG.

Financial support. This research has been supported by the German Federal Ministry of Education and Research (grant no. 01LK1212C), the National Natural Science Foundation of China (91644218), the National Key R\&D Program of China (2017YFC0210104) and Guangdong Innovative and Entrepreneurial Research Team Program (2016ZT06N263).

The publication of this article was funded by the Open Access Fund of the Leibniz Association.

Review statement. This paper was edited by Pedro JimenezGuerrero and reviewed by Daniel Neumann and one anonymous referee.

\section{References}

Abdelkader, M., Metzger, S., Mamouri, R. E., Astitha, M., Barrie, L., Levin, Z., and Lelieveld, J.: Dust-air pollution dynamics over the eastern Mediterranean, Atmos. Chem. Phys., 15, 9173-9189, https://doi.org/10.5194/acp-15-9173-2015, 2015.

Adams, P. J., Seinfeld, J. H., Koch, D., Mickley, L., and Jacob, D.: General circulation model assessment of direct radiative forcing by the sulfate-nitrate-ammonium-water inorganic aerosol system, J. Geophys. Res.-Atmos., 106, 1097-1111, https://doi.org/10.1029/2000JD900512, 2001.

AERONET: Aerosol Robotic Network, available at: https://aeronet. gsfc.nasa.gov/, last access: 21 January 2020.

Archer-Nicholls, S., Lowe, D., Utembe, S., Allan, J., Zaveri, R. A., Fast, J. D., Hodnebrog, Ø., Denier van der Gon, H., and McFiggans, G.: Gaseous chemistry and aerosol mechanism developments for version 3.5.1 of the online regional model, WRF-Chem, Geosci. Model Dev., 7, 2557-2579, https://doi.org/10.5194/gmd-7-2557-2014, 2014.

Archer-Nicholls, S., Lowe, D., Lacey, F., Kumar, R., Xiao, Q., Liu, Y., Carter, E., Baumgartner, J., and Wiedinmyer, C.: Radiative Effects of Residential Sector Emissions in China: Sensitivity to Uncertainty in Black Carbon Emissions, J. Geophys. Res.-Atmos., 124, 5029-5044, https://doi.org/10.1029/2018JD030120, 2019.

AQMEII: Air Quality Modelling Evaluation International Initiative, available at: http://aqmeii.jrc.ec.europa.eu/, last access: 21 January 2020 .
Bauer, S. E., Koch, D., Unger, N., Metzger, S. M., Shindell, D. T., and Streets, D. G.: Nitrate aerosols today and in 2030: a global simulation including aerosols and tropospheric ozone, Atmos. Chem. Phys., 7, 5043-5059, https://doi.org/10.5194/acp-7-50432007, 2007.

Bellouin, N., Rae, J., Jones, A., Johnson, C., Haywood, J., and Boucher, O.: Aerosol forcing in the Climate Model Intercomparison Project (CMIP5) simulations by HadGEM2-ES and the role of ammonium nitrate, J. Geophys. Res.-Atmos., 116, D20206, https://doi.org/10.1029/2011JD016074, 2011.

Berner, A. and Luerzer, C.: Mass size distributions of traffic aerosols at Vienna, J. Phys. Chem., 84, 2079-2083, https://doi.org/10.1021/j100453a016, 1980.

Bertram, T. H. and Thornton, J. A.: Toward a general parameterization of $\mathrm{N}_{2} \mathrm{O}_{5}$ reactivity on aqueous particles: the competing effects of particle liquid water, nitrate and chloride, Atmos. Chem. Phys., 9, 8351-8363, https://doi.org/10.5194/acp-9-8351-2009, 2009.

Birmili, W., Wiedensohler, A., Heintzenberg, J., and Lehmann, K.: Atmospheric particle number size distribution in central Europe: Statistical relations to air masses and meteorology, J. Geophys. Res., 106, 32005-32018, https://doi.org/10.1029/2000JD000220, 2001

Chen, Y., Zhao, C., Zhang, Q., Deng, Z. Z., Huang, M. Y., and Ma, X. C.: Aircraft study of mountain chimney effect of Beijing, china, J. Geophys. Res.-Atmos., 114, D08306, https://doi.org/10.1029/2008JD010610, 2009.

Chen, Y., Cheng, Y., Ma, N., Wolke, R., Nordmann, S., Schüttauf, S., Ran, L., Wehner, B., Birmili, W., van der Gon, H. A. C. D., Mu, Q., Barthel, S., Spindler, G., Stieger, B., Müller, K., Zheng, G.-J., Pöschl, U., Su, H., and Wiedensohler, A.: Sea salt emission, transport and influence on sizesegregated nitrate simulation: a case study in northwestern Europe by WRF-Chem, Atmos. Chem. Phys., 16, 12081-12097, https://doi.org/10.5194/acp-16-12081-2016, 2016a.

Chen, Y., Cheng, Y.-F., Nordmann, S., Birmili, W., Denier van der Gon, H. A. C., Ma, N., Wolke, R., Wehner, B., Sun, J., Spindler, G., Mu, Q., Pöschl, U., Su, H., and Wiedensohler, A.: Evaluation of the size segregation of elemental carbon (EC) emission in Europe: influence on the simulation of EC long-range transportation, Atmos. Chem. Phys., 16, 1823-1835, https://doi.org/10.5194/acp-16-1823-2016, 2016b.

Chen, Y., Wild, O., Wang, Y., Ran, L., Teich, M., Größ, J., Wang, L., Spindler, G., Herrmann, H., van Pinxteren, D., McFiggans, G., and Wiedensohler, A.: The influence of impactor size cut-off shift caused by hygroscopic growth on particulate matter loading and composition measurements, Atmos. Environ., 195, 141-148, https://doi.org/10.1016/j.atmosenv.2018.09.049, 2018a.

Chen, Y., Wolke, R., Ran, L., Birmili, W., Spindler, G., Schröder, W., Su, H., Cheng, Y., Tegen, I., and Wiedensohler, A.: A parameterization of the heterogeneous hydrolysis of $\mathrm{N}_{2} \mathrm{O}_{5}$ for mass-based aerosol models: improvement of particulate nitrate prediction, Atmos. Chem. Phys., 18, 673-689, https://doi.org/10.5194/acp-18-673-2018, 2018b.

Chen, Y., Lelieveld, J., and Pozzer, A.: EMAC_2010.nc, Lancaster University, https://doi.org/10.17635/lancaster/researchdata/297, 2020.

Chou, M.-D., Suarez, M. J., Ho, C.-H., Yan, M. M. H., and Lee, K.-T.: Parameterizations for Cloud Overlap- 
ping and Shortwave Single-Scattering Properties for Use in General Circulation and Cloud Ensemble Models, J. Climate, 11, 202-214, https://doi.org/10.1175/15200442(1998)011<0202:PFCOAS>2.0.CO;2, 1998.

Croft, B., Pierce, J. R., and Martin, R. V.: Interpreting aerosol lifetimes using the GEOS-Chem model and constraints from radionuclide measurements, Atmos. Chem. Phys., 14, 4313-4325, https://doi.org/10.5194/acp-14-4313-2014, 2014.

Ding, A., Wang, T., Zhao, M., Wang, T., and Li, Z.: Simulation of sea-land breezes and a discussion of their implications on the transport of air pollution during a multi-day ozone episode in the Pearl River Delta of China, Atmos. Environ., 38, 6737-6750, https://doi.org/10.1016/j.atmosenv.2004.09.017, 2004.

Dupart, Y., King, S. M., Nekat, B., Nowak, A., Wiedensohler, A., Herrmann, H., David, G., Thomas, B., Miffre, A., Rairoux, P., D'Anna, B., and George, C.: Mineral dust photochemistry induces nucleation events in the presence of $\mathrm{SO}_{2}$, P. Natl. Acad. Sci. USA, 109, 20842-20847, https://doi.org/10.1073/pnas.1212297109, 2012.

EBAS: Observation data of atmospheric chemical composition and physical properties, available at: http://ebas.nilu.no/default.aspx, last access: 21 January 2020.

EDGAR: Emissions Database for Global Atmospheric Research, available at: http://edgar.jrc.ec.europa.eu, last access: 21 January 2020.

EUCAARI: European Integrated project on Aerosol, Cloud, Climate, and Air Quality Interactions, available at: https://www.atm. helsinki.fi/eucaari/?q=node/3, last access: 21 January 2020.

Fast, J. D., Gustafson Jr., W. I., Easter, R. C., Zaveri, R. A., Barnard, J. C., Chapman, E. G., Grell, G. A., and Peckham, S. E.: Evolution of ozone, particulates, and aerosol direct radiative forcing in the vicinity of Houston using a fully coupled meteorology-chemistry-aerosol model, J. Geophys. Res.-Atmos., 111, D21305, https://doi.org/10.1029/2005JD006721, 2006.

Forster, P., Ramaswamy, V., Artaxo, P., Berntsen, T., Betts, R., Fahey, D. W., Haywood, J., Lean, J., Lowe, D. C., Myhre, G., Nganga, J., Prinn, R., Raga, G., Schulz, M., and Van Dorland, R.: Changes in Atmospheric Constituents and in Radiative Forcing, in: Climate Change 2007: The Physical Science Basis. Contribution of Working Group I to the Fourth Assessment Report of the Intergovernmental Panel on Climate Change, edited by: Solomon, S., Qin, D., Manning, M., Chen, Z., Marquis, M., Averyt, K. B., Tignor, M., and Miller, H. L., Cambridge University Press, Cambridge, United Kingdom and New York, NY, USA, 2007.

Gantt, B., Kelly, J. T., and Bash, J. O.: Updating sea spray aerosol emissions in the Community Multiscale Air Quality (CMAQ) model version 5.0.2, Geosci. Model Dev., 8, 37333746, https://doi.org/10.5194/gmd-8-3733-2015, 2015.

Gao, M., Ji, D., Liang, F., and Liu, Y.: Attribution of aerosol direct radiative forcing in China and India to emitting sectors, Atmos. Environ., 190, 35-42, https://doi.org/10.1016/j.atmosenv.2018.07.011, 2018.

Gong, S. L.: A parameterization of sea-salt aerosol source function for sub- and super-micron particles, Global Biogeochem. Cy., 17, 1097, https://doi.org/10.1029/2003GB002079, 2003.

Grell, G. A., Peckham, S. E., Schmitz, R., McKeen, S. A., Frost, G., Skamarock, W. C., and Eder, B.: Fully coupled "online" chem- istry within the WRF model, Atmos. Environ., 39, 6957-6975, https://doi.org/10.1016/j.atmosenv.2005.04.027, 2005.

Gustafsson, M. E. R. and Franzén, L. G.: Inland transport of marine aerosols in southern Sweden, Atmos. Environ., 34, 313-325, https://doi.org/10.1016/S1352-2310(99)00198-3, 2000.

Harris, E., Sinha, B., van Pinxteren, D., Tilgner, A., Fomba, K. W., Schneider, J., Roth, A., Gnauk, T., Fahlbusch, B., Mertes, S., Lee, T., Collett, J., Foley, S., Borrmann, S., Hoppe, P., and Herrmann, H.: Enhanced Role of Transition Metal Ion Catalysis During In-Cloud Oxidation of $\mathrm{SO}_{2}$, Science, 340, 727-730, https://doi.org/10.1126/science.1230911, 2013.

Hauglustaine, D. A., Balkanski, Y., and Schulz, M.: A global model simulation of present and future nitrate aerosols and their direct radiative forcing of climate, Atmos. Chem. Phys., 14, 1103111063, https://doi.org/10.5194/acp-14-11031-2014, 2014.

Haywood, J. and Schulz, M.: Causes of the reduction in uncertainty in the anthropogenic radiative forcing of climate between IPCC (2001) and IPCC (2007), Geophys. Res. Lett., 34, L20701, https://doi.org/10.1029/2007GL030749, 2007.

Hong, S.-Y., Noh, Y., and Dudhia, J.: A new vertical diffusion package with an explicit treatment of entrainment processes, Mon. Weather Rev., 134, 2318-2341, 2006.

Huang, X., Song, Y., Zhao, C., Cai, X., Zhang, H., and Zhu, T.: Direct Radiative Effect by Multicomponent Aerosol over China, J. Climate, 28, 3472-3495, https://doi.org/10.1175/JCLI-D-1400365.1, 2015.

IPCC: Climate Change 2013: The Physical Science Basis. Contribution of Working Group I to the Fifth Assessment Report of the Intergovernmental Panel on Climate Change, Report, edited by: Stocker, T. F., Qin D. H., Plattner, G. K., Tignor, M. M. B., Allen, S. K., Boschung, J., Nauels, A., Xia, Y., Bex, V., and Midgley, P. M., Cambridge University Press, New York, available at: http://www.ipcc.ch/report/ar5 (last access: 10 September 2016), 2013.

Itahashi, S., Hayami, H., Uno, I., Pan, X., and Uematsu, M.: Importance of coarse-mode nitrate produced via sea salt as atmospheric input to East Asian oceans, Geophys. Res. Lett., 43, 5483-5491, https://doi.org/10.1002/2016GL068722, 2016.

Jacobson, M. Z.: Global direct radiative forcing due to multicomponent anthropogenic and natural aerosols, J. Geophys. Res.-Atmos., 106, 1551-1568, https://doi.org/10.1029/2000JD900514, 2001.

Jöckel, P., Kerkweg, A., Pozzer, A., Sander, R., Tost, H., Riede, H., Baumgaertner, A., Gromov, S., and Kern, B.: Development cycle 2 of the Modular Earth Submodel System (MESSy2), Geosci. Model Dev., 3, 717-752, https://doi.org/10.5194/gmd-3717-2010, 2010.

Karydis, V. A., Tsimpidi, A. P., Pozzer, A., Astitha, M., and Lelieveld, J.: Effects of mineral dust on global atmospheric nitrate concentrations, Atmos. Chem. Phys., 16, 1491-1509, https://doi.org/10.5194/acp-16-1491-2016, 2016.

Klingmüller, K., Steil, B., Brühl, C., Tost, H., and Lelieveld, J.: Sensitivity of aerosol radiative effects to different mixing assumptions in the AEROPT 1.0 submodel of the EMAC atmosphericchemistry-climate model, Geosci. Model Dev., 7, 2503-2516, https://doi.org/10.5194/gmd-7-2503-2014, 2014.

Köhler, H.: The nucleus in and the growth of hygroscopic droplets, T. Faraday Soc., 32, 1152-1161, https://doi.org/10.1039/TF9363201152, 1936. 
Kok, J. F., Ridley, D. A., Zhou, Q., Miller, R. L., Zhao, C., Heald, C. L., Ward, D. S., Albani, S., and Haustein, K.: Smaller desert dust cooling effect estimated from analysis of dust size and abundance, Nat. Geosci., 10, 274-278, https://doi.org/10.1038/ngeo2912, 2017.

Kottek, M., Grieser, J., Beck, C., Rudolf, B., and Rubel, F.: World Map of the Köppen-Geiger climate classification updated, Meteorol. Z., 15, 259-263, https://doi.org/10.1127/09412948/2006/0130, 2006.

Kulmala, M., Asmi, A., Lappalainen, H. K., Baltensperger, U., Brenguier, J.-L., Facchini, M. C., Hansson, H.-C., Hov, Ø., O'Dowd, C. D., Pöschl, U., Wiedensohler, A., Boers, R., Boucher, O., de Leeuw, G., Denier van der Gon, H. A. C., Feichter, J., Krejci, R., Laj, P., Lihavainen, H., Lohmann, U., McFiggans, G., Mentel, T., Pilinis, C., Riipinen, I., Schulz, M., Stohl, A., Swietlicki, E., Vignati, E., Alves, C., Amann, M., Ammann, M., Arabas, S., Artaxo, P., Baars, H., Beddows, D. C. S., Bergström, R., Beukes, J. P., Bilde, M., Burkhart, J. F., Canonaco, F., Clegg, S. L., Coe, H., Crumeyrolle, S., D'Anna, B., Decesari, S., Gilardoni, S., Fischer, M., Fjaeraa, A. M., Fountoukis, C., George, C., Gomes, L., Halloran, P., Hamburger, T., Harrison, R. M., Herrmann, H., Hoffmann, T., Hoose, C., Hu, M., Hyvärinen, A., Hõrrak, U., Iinuma, Y., Iversen, T., Josipovic, M., Kanakidou, M., Kiendler-Scharr, A., Kirkevåg, A., Kiss, G., Klimont, Z., Kolmonen, P., Komppula, M., Kristjánsson, J.-E., Laakso, L., Laaksonen, A., Labonnote, L., Lanz, V. A., Lehtinen, K. E. J., Rizzo, L. V., Makkonen, R., Manninen, H. E., McMeeking, G., Merikanto, J., Minikin, A., Mirme, S., Morgan, W. T., Nemitz, E., O’Donnell, D., Panwar, T. S., Pawlowska, H., Petzold, A., Pienaar, J. J., Pio, C., Plass-Duelmer, C., Prévôt, A. S. H., Pryor, S., Reddington, C. L., Roberts, G., Rosenfeld, D., Schwarz, J., Seland, Ø., Sellegri, K., Shen, X. J., Shiraiwa, M., Siebert, H., Sierau, B., Simpson, D., Sun, J. Y., Topping, D., Tunved, P., Vaattovaara, P., Vakkari, V., Veefkind, J. P., Visschedijk, A., Vuollekoski, H., Vuolo, R., Wehner, B., Wildt, J., Woodward, S., Worsnop, D. R., van Zadelhoff, G.J., Zardini, A. A., Zhang, K., van Zyl, P. G., Kerminen, V.M., S Carslaw, K., and Pandis, S. N.: General overview: European Integrated project on Aerosol Cloud Climate and Air Quality interactions (EUCAARI) - integrating aerosol research from nano to global scales, Atmos. Chem. Phys., 11, 13061-13143, https://doi.org/10.5194/acp-11-13061-2011, 2011.

Li, S., Garay, M. J., Chen, L., Rees, E., and Liu, Y.: Comparison of GEOS-Chem aerosol optical depth with AERONET and MISR data over the contiguous United States, J. Geophys. Res.-Atmos., 118, 11228-11241, https://doi.org/10.1002/jgrd.50867, 2013.

Liao, H. and Seinfeld, J. H.: Global impacts of gas-phase chemistryaerosol interactions on direct radiative forcing by anthropogenic aerosols and ozone, J. Geophys. Res.-Atmos., 110, D18208, https://doi.org/10.1029/2005JD005907, 2005.

Liao, H., Seinfeld, J. H., Adams, P. J., and Mickley, L. J.: Global radiative forcing of coupled tropospheric ozone and aerosols in a unified general circulation model, J. Geophys. Res.-Atmos., 109, D16207, https://doi.org/10.1029/2003JD004456, 2004.

Lin, Y., Farley, R., and Orville, H.: Bulk Parameterization of the Snow Field in a Cloud Model, J. Clim. Appl. Meteorol., 22, 1065-1092, 1983.

Lowe, D., Archer-Nicholls, S., Morgan, W., Allan, J., Utembe, S., Ouyang, B., Aruffo, E., Le Breton, M., Zaveri, R. A., Di
Carlo, P., Percival, C., Coe, H., Jones, R., and McFiggans, G.: WRF-Chem model predictions of the regional impacts of $\mathrm{N}_{2} \mathrm{O}_{5}$ heterogeneous processes on night-time chemistry over north-western Europe, Atmos. Chem. Phys., 15, 1385-1409, https://doi.org/10.5194/acp-15-1385-2015, 2015.

Macke, A., Seifert, P., Baars, H., Barthlott, C., Beekmans, C., Behrendt, A., Bohn, B., Brueck, M., Bühl, J., Crewell, S., Damian, T., Deneke, H., Düsing, S., Foth, A., Di Girolamo, P., Hammann, E., Heinze, R., Hirsikko, A., Kalisch, J., Kalthoff, N., Kinne, S., Kohler, M., Löhnert, U., Madhavan, B. L., Maurer, V., Muppa, S. K., Schween, J., Serikov, I., Siebert, H., Simmer, C., Späth, F., Steinke, S., Träumner, K., Trömel, S., Wehner, B., Wieser, A., Wulfmeyer, V., and Xie, X.: The HD(CP $)^{2}$ Observational Prototype Experiment (HOPE) - an overview, Atmos. Chem. Phys., 17, 4887-4914, https://doi.org/10.5194/acp17-4887-2017, 2017.

May, N. W., Gunsch, M. J., Olson, N., Bondy, A. L., Kirpes, R. M., Bertman, S., China, S., Laskin, A., Hopke, P. K., Ault, A. P., and Pratt, K. A.: Unexpected contributions of sea spray and lake spray aerosol to inland particulate matter, Environ. Sci. Tech. Let., 5, 405-412, https://doi.org/10.1021/acs.estlett.8b00254, 2018.

Murphy, D. M., Anderson, J. R., Quinn, P. K., McInnes, L. M., Brechtel, F. J., Kreidenweis, S. M., Middlebrook, A. M., Posfai, M., Thomson, D. S., and Buseck, P. R.: Influence of sea-salt on aerosol radiative properties in the Southern Ocean marine boundary layer, Nature, 392, 62-65, 1998.

Myhre, G., Grini, A., and Metzger, S.: Modelling of nitrate and ammonium-containing aerosols in presence of sea salt, Atmos. Chem. Phys., 6, 4809-4821, https://doi.org/10.5194/acp-6-48092006, 2006.

Myhre, G., Samset, B. H., Schulz, M., Balkanski, Y., Bauer, S., Berntsen, T. K., Bian, H., Bellouin, N., Chin, M., Diehl, T., Easter, R. C., Feichter, J., Ghan, S. J., Hauglustaine, D., Iversen, T., Kinne, S., Kirkevåg, A., Lamarque, J.-F., Lin, G., Liu, X., Lund, M. T., Luo, G., Ma, X., van Noije, T., Penner, J. E., Rasch, P. J., Ruiz, A., Seland, Ø., Skeie, R. B., Stier, P., Takemura, T., Tsigaridis, K., Wang, P., Wang, Z., Xu, L., Yu, H., Yu, F., Yoon, J.-H., Zhang, K., Zhang, H., and Zhou, C.: Radiative forcing of the direct aerosol effect from AeroCom Phase II simulations, Atmos. Chem. Phys., 13, 1853-1877, https://doi.org/10.5194/acp13-1853-2013, 2013.

NCAR/UCAR: Atmospheric Chemistry Observations \& Modeling, available at: https://www2.acom.ucar.edu, last access: 21 January 2020.

NCEP/National Weather Service/NOAA/U.S. Department of Commerce: NCEP reanalysis dataset, available at: https://rda.ucar. edu/data/ds083.2/ (last access: 21 January 2020), 2000 (updated daily).

NCEP SST: NCEP sea surface temperature, available at: https: //polar.ncep.noaa.gov/sst/, last access: 16 December 2019.

Neumann, D., Matthias, V., Bieser, J., Aulinger, A., and Quante, M.: A comparison of sea salt emission parameterizations in northwestern Europe using a chemistry transport model setup, Atmos. Chem. Phys., 16, 9905-9933, https://doi.org/10.5194/acp16-9905-2016, 2016.

Neusüß, C., Weise, D., Birmili, W., Wex, H., Wiedensohler, A., and Covert, D. S.: Size-segregated chemical, gravimetric and number distribution-derived mass closure of the aerosol 
in Sagres, Portugal during ACE-2, Tellus B, 52, 169-184, https://doi.org/10.1034/j.1600-0889.2000.00039.x, 2000.

O'Dowd, C. D., Smith, M. H., Consterdine, I. E., and Lowe, J. A.: Marine aerosol, sea-salt, and the marine sulphur cycle: a short review, Atmos. Environ., 31, 73-80, https://doi.org/10.1016/S1352-2310(96)00106-9, 1997.

Petters, M. D. and Kreidenweis, S. M.: A single parameter representation of hygroscopic growth and cloud condensation nucleus activity, Atmos. Chem. Phys., 7, 1961-1971, https://doi.org/10.5194/acp-7-1961-2007, 2007.

Ponczek, M. and George, C.: Kinetics and Product Formation during the Photooxidation of Butanol on Atmospheric Mineral Dust, Environ. Sci. Technol., 52, 5191-5198, https://doi.org/10.1021/acs.est.7b06306, 2018.

Pouliot, G., Pierce, T., Denier van der Gon, H., Schaap, M., Moran, M., and Nopmongcol, U.: Comparing emission inventories and model-ready emission datasets between Europe and North America for the AQMEII project, Atmos. Environ., 53, 414, https://doi.org/10.1016/j.atmosenv.2011.12.041, 2012.

Pozzer, A., de Meij, A., Pringle, K. J., Tost, H., Doering, U. M., van Aardenne, J., and Lelieveld, J.: Distributions and regional budgets of aerosols and their precursors simulated with the EMAC chemistry-climate model, Atmos. Chem. Phys., 12, 961-987, https://doi.org/10.5194/acp-12-961-2012, 2012.

Pringle, K. J., Tost, H., Message, S., Steil, B., Giannadaki, D., Nenes, A., Fountoukis, C., Stier, P., Vignati, E., and Lelieveld, J.: Description and evaluation of GMXe: a new aerosol submodel for global simulations (v1), Geosci. Model Dev., 3, 391-412, https://doi.org/10.5194/gmd-3-391-2010, 2010.

Ravishankara, A. R.: Heterogeneous and Multiphase Chemistry in the Troposphere, Science, 276, 1058-1065, https://doi.org/10.1126/science.276.5315.1058, 1997.

Saide, P. E., Spak, S. N., Carmichael, G. R., Mena-Carrasco, M. A., Yang, Q., Howell, S., Leon, D. C., Snider, J. R., Bandy, A. R., Collett, J. L., Benedict, K. B., de Szoeke, S. P., Hawkins, L. N., Allen, G., Crawford, I., Crosier, J., and Springston, S. R.: Evaluating WRF-Chem aerosol indirect effects in Southeast Pacific marine stratocumulus during VOCALS-REx, Atmos. Chem. Phys., 12, 3045-3064, https://doi.org/10.5194/acp12-3045-2012, 2012.

Seinfeld, J. H. and Pandis, S. N.: Atmospheric Chemistry and Physics: From Air Pollution to Climate Change, John Wiley \& Sons, New York, 2nd Edn., 2006.

Spindler, G., Gnauk, T., Grüner, A., Iinuma, Y., Müller, K., Scheinhardt, S., and Herrmann, H.: Size-segregated characterization of PM10 at the EMEP site Melpitz (Germany) using a fivestage impactor: a six year study, J. Atmos. Chem., 69, 127-157, https://doi.org/10.1007/s10874-012-9233-6, 2012.

Streets, D. G., Shindell, D. T., Lu, Z., and Faluvegi, G.: Radiative forcing due to major aerosol emitting sectors in China and India, Geophys. Res. Lett., 40, 4409-4414, https://doi.org/10.1002/grl.50805, 2013.
Usher, C. R., Michel, A. E., and Grassian, V. H.: Reactions on Mineral Dust, Chem. Rev., 103, 4883-4940, https://doi.org/10.1021/cr020657y, 2003.

van Dorland, R., Dentener, F. J., and Lelieveld, J.: Radiative forcing due to tropospheric ozone and sulfate aerosols, J. Geophys. Res.Atmos., 102, 28079-28100, https://doi.org/10.1029/97JD02499, 1997.

Vivanco, M. G., Bessagnet, B., Cuvelier, C., Theobald, M. R., Tsyro, S., Pirovano, G., Aulinger, A., Bieser, J., Calori, G., Ciarelli, G., Manders, A., Mircea, M., Aksoyoglu, S., Briganti, G., Cappelletti, A., Colette, A., Couvidat, F., D’Isidoro, M., Kranenburg, R., Meleux, F., Menut, L., Pay, M. T., Rouïl, L., Silibello, C., Thunis, P., and Ung, A.: Joint analysis of deposition fluxes and atmospheric concentrations of inorganic nitrogen and sulphur compounds predicted by six chemistry transport models in the frame of the EURODELTAIII project, Atmos. Environ., 151, 152-175, https://doi.org/10.1016/j.atmosenv.2016.11.042, 2017.

Wang, Y. and Chen, Y.: Significant Climate Impact of Highly Hygroscopic Atmospheric Aerosols in Delhi, India, Geophys. Res. Lett., 46, 5535-5545, https://doi.org/10.1029/2019GL082339, 2019.

Wiedinmyer, C., Akagi, S. K., Yokelson, R. J., Emmons, L. K., AlSaadi, J. A., Orlando, J. J., and Soja, A. J.: The Fire INventory from NCAR (FINN): a high resolution global model to estimate the emissions from open burning, Geosci. Model Dev., 4, 625641, https://doi.org/10.5194/gmd-4-625-2011, 2011.

Wild, O., Zhu, X., and Prather, M. J.: Fast-J: Accurate Simulation of In- and Below-Cloud Photolysis in Tropospheric Chemical Models, J. Atmos. Chem., 37, 245-282, 2000.

$\mathrm{Xu}, \mathrm{L}$. and Penner, J. E.: Global simulations of nitrate and ammonium aerosols and their radiative effects, Atmos. Chem. Phys., 12, 9479-9504, https://doi.org/10.5194/acp-12-94792012, 2012.

Yao, H., Song, Y., Liu, M., Archer-Nicholls, S., Lowe, D., McFiggans, G., Xu, T., Du, P., Li, J., Wu, Y., Hu, M., Zhao, C., and Zhu, T.: Direct radiative effect of carbonaceous aerosols from crop residue burning during the summer harvest season in East China, Atmos. Chem. Phys., 17, 5205-5219, https://doi.org/10.5194/acp-17-5205-2017, 2017.

Zaveri, R. A. and Peters, L. K.: A new lumped structure photochemical mechanism for large-scale applications, J. Geophys. Res., 104, 30387-30415, 1999.

Zaveri, R. A., Easter, R. C., Fast, J. D., and Peters, L. K.: Model for Simulating Aerosol Interactions and Chemistry (MOSAIC), J. Geophys. Res.-Atmos., 113, D13204, https://doi.org/10.1029/2007JD008782, 2008. 